\title{
Glutathionylation: a regulatory role of glutathione in physiological processes
}

\author{
Kristina Dominko ${ }^{1}$ and Domagoj Đikić ${ }^{2}$ \\ Division of Molecular Medicine, Ruđer Bošković Institutel, Department of Animal Physiology, Faculty of Science, \\ University of Zagreb², Zagreb, Croatia
}

[Received in March 2017; Similarity Check in March 2017; Accepted in March 2018]

\begin{abstract}
Glutathione ( $\gamma$-glutamyl-cysteinyl-glycine) is an intracellular thiol molecule and a potent antioxidant that participates in the toxic metabolism phase II biotransformation of xenobiotics. It can bind to a variety of proteins in a process known as glutathionylation. Protein glutathionylation is now recognised as one of important posttranslational regulatory mechanisms in cell and tissue physiology. Direct and indirect regulatory roles in physiological processes include glutathionylation of major transcriptional factors, eicosanoids, cytokines, and nitric oxide (NO). This review looks into these regulatory mechanisms through examples of glutathione regulation in apoptosis, vascularisation, metabolic processes, mitochondrial integrity, immune system, and neural physiology. The focus is on the physiological roles of glutathione beyond biotransformational metabolism.
\end{abstract}

KEY WORDS: epigenetics; GSH; GSSG; immunity; transcriptional factors

From the toxicological point of view, $\gamma$-glutamylcysteinylglycine or glutathione is an important molecule in toxin metabolism and biotransformation of xenobiotics, as it converts several classes of compounds through conjugation. Conjugated electrophiles include various complex natural molecules, environmental chemicals, and drugs (1). Phase II conjugations are well known to toxicology (2-5). Glutathione participates in the defence against reactive oxygen species (ROS) and has a role as an antioxidant, as it metabolises oxygen radicals and peroxides and establishes intracellular redox balance (6).

It binds to other endogenous molecules forming, for example, the haemoglobin-glutathione complex, which serves as one of the markers of oxidative stress in human blood (7). With the advancement of detection methods in recent years (such as redox proteomic techniques and others), we have also learned about a vast number of interactions between glutathione and cellular proteins $(8,9)$.

We usually note the glutathione imbalance under various physiological conditions, and literature keeps demonstrating its regulatory roles in organisms (10-13).

The aim of this review is to summarise current knowledge about direct and indirect mechanisms of redox regulation and glutathionylation, which could serve as a guide to glutathione functions beside the ones usually described and evaluated by toxicologists.

Correspondence to: Domagoj Đikić, PhD, Department of Animal Physiology, Faculty of Science, University of Zagreb, Rooseveltov trg 6, 10000 Zagreb, Croatia, E-mail: magistar_djikic1@yahoo.com

\section{PHYSIOLOGY AND TRANSCRIPTIONAL REGULATION OF GLUTATHIONE METABOLISM}

Glutathione is a low-molecular-weight tripeptide present in microorganisms, plants, and mammals. It consists of cysteine (Cys), glutamic acid, and glycine and can be free or bound to proteins. In eukaryotic cells it can be a powerful enzyme cofactor. Its active site is the thiol (-SH) group of the Cys residue at which conjugation reactions take place. Most often, glutathione appears in its reduced form (GSH), but it can also appear in its oxidised disulphide (GSSG) form. The normal ratio between GSH and GSSG (GSH/GSSG) in the cytoplasm and mitochondria is $>10$ to 1 and in human serum it is 6-10 to 1 .

Its concentrations in the cells are usually in millimolar ranges (7). It is the most abundant of all cellular thiols, which contain more than $90 \%$ of the total nonprotein sulphur in tissues. About $90 \%$ of GSH is located in the cytosol, while the remaining $10 \%$ is located in the mitochondria, endoplasmic reticulum, and even in the nucleus $(7,14-17)$. In the endoplasmic reticulum it regulates internal proteins (18). It can shift from one cellular compartment to the other. For example, it shifts from the cytosol to the mitochondrial matrix thanks to mitochondrial transporter proteins $(9,19)$.

GSH is synthesised by all organs, liver in particular. GSH in the liver has a rapid turnover, with half-life of approximately $2-3$ h. (7, 20-24). High concentrations are also found in the bile acid, up to $10 \mathrm{mmol} \mathrm{L}^{-1}$. Its concentrations can be high in various blood cells and other 
tissues $(7,20)$, even in the vitreous of the eye (13). GSH levels adapt to physiological needs; in the oocyte, for instance, they keep around $7 \mathrm{mmol} \mathrm{L}^{-1}$ but drop rapidly to nearly $0 \mathrm{mmol} \mathrm{L}^{-1}$ after fertilisation and stay that low until the $3^{\text {rd }}$ day of the blastocyst phase. After day 7 , in the gastrulation phase, GSH levels rise with cell division to about $2 \mathrm{mmol} \mathrm{L}^{-1}(25)$.

Hansen and Harris (25) provide a comprehensive comparison of glutathione tissue concentrations between species that can serve as biomedical models. It is a valuable reference for the comparison with experimental data obtained in various biomedical and toxicological studies utilising in vivo models.

\section{REGULATION OF PROTEIN ACTIVITY BY REDOX BALANCE AND GLUTATHIONYLATION}

Redox status and radical species [such as ROS and reactive nitrogen species (RNS)] posttranslationally modulate metabolic pathways and signal transduction in cell necrosis, apoptosis, and proliferation. They govern signal proteins in inflammatory and toxic reactions and regulate the binding of transcriptional factors to cognate DNA (23, 26-30). Brigelius-Flohe and Flohe (8) have published a most comprehensive review of the principles of redox and ROS regulation of proteins and cellular processes.

Glutathione participates in these regulatory mechanisms, too. It regulates protein activity in two ways. The first by indirectly changing protein charge and redox state (without binding directly to a protein) and therefore modulating protein action. The second is by directly binding to proteins and forming disulphide bonds (P-SSG). This second process is known as glutathionylation.

\section{Glutathionylation}

Glutathionylation is a thiol modification of proteins that complement other posttranslational regulatory mechanisms such as phosphorylation, acetylation, methylation, ubiquitination, glucuronidation, and palmitoylation in the cell $(8,9)$. In some cases, a protein can be phosphorylated and glutathionylated on different amino acid residues at the same time. Combinations of these posttranslational modifications modulate and fine tune protein activity. In the cell, glutathione reversibly binds to various structural, signalling, regulatory, receptor, or channel proteins and transcriptional factors involved in maintaining cell and tissue homeostasis or in pathophysiological processes (9).

The extent of glutathionylation greatly depends on the GSH/GSSG ratio in the cell. Usually, the higher the GSSG content (and GSH/GSSG ratio of 1:1 towards 1:10), the stronger the glutathione binding $(8,9,16,19)$. Proteins interact with GSH by forming P-SSG bonds on Cys residues of both the protein and GSH. Other cellular thiols complement glutathionylation. Proteins bind other thiols beside glutathione by forming disulphide (P-SS) bonds or even thiol disulphide bonds between proteins (P-SS-P) as part of regulatory activities.

Glutathionylation and deglutathionylation are highly regulated biochemical processes. Glutathionylation is usually preceded by several biochemical intermediary changes on the protein. Sometimes it is preceded by other thiol-protein interactions (P-SS or P-SS-P), whose aim is to activate reaction. Similarly, glutathionylation is sometimes preceded by redox changes in target proteins (change of protein charges) initiated by ROS or redox imbalance, activation of RNS, or nitrosoglutathione (GSNO) $(8,9,31,32)$. Sometimes interactions between proteins and thiols can also create sulphenic ( $\mathrm{SOH}$ ), sulphinic $\left(\mathrm{SO}_{2} \mathrm{H}\right)$, and sulphonic $\left(\mathrm{SO}_{3} \mathrm{H}\right)$ or $S$-nitrosothiol (P-SNO) formations that damage proteins (similar to ROS) and lead to cell death. Repair of proteins damaged in this way is regulated by the thioredoxin (TRX, EC 1.8.4.8) enzymes.

\section{Enzymes in glutathione reactions and glutathionylation}

The overall glutathione metabolism and shuttling is governed by an array of enzymes in the cell. In the Phase II conjugation reactions glutathione $S$-transferase (GST, EC 2.5.1.18) catalyses reactions between reactive electrophiles and GSH to form xenobiotic conjugates (GS-X). Being an antioxidant, GSH metabolises intracellular oxygen radicals and peroxides, principally through enzymes such as glutathione peroxidase (GPx, EC 1.11.1.9, forms 1-8 in human) and peroxiredoxins (PRDXs, EC 1.11.1.15, 1-7 in humans), which, in turn, restore cellular redox balance. Enzymes that reversibly convert GSH and GSSG are GPx and glutathione reductase (approved name glutathionedisulphide reductase, GR, EC 1.8.1.7) (20, 33-37). Glutathione S-transferase P (GSTP or GSTP $\pi$, EC 2.5.1.18) catalyses S-glutathionylation of proteins, and glutaredoxin-1 (GLRX1, EC 1.20.4.1) catalyses deglutathionylation of proteins $(5,9,19,38)$. During glutathionylation, GSTP binds GSH and lowers the dissociation constant $(\mathrm{pKa})$ of the thiols, creating a thiolate anion $\left(\mathrm{GS}^{-}\right)$as the active site for protein binding. Other GSH-dependent enzymes involved in glutathionylation are glutathione $S$-transferase omega 1 (GSTO1) (39), GR, GPx, PRDX, GST, membraneassociated proteins involved in eicosanoid and glutathione metabolism (MAPEG) superfamily of enzymes, and sometimes even glyoxalase I (or lactoylglutathione lyase, GloI, EC 4.4.1.5) and glyoxalase II (or hydroxyacylglutathione hydrolase, GloII, EC 3.1.2.6). Each of these enzymes can participate in protein glutathionylation. Glutathionylation of proteins is also regulated by thioredoxins (mentioned above as enzymes that repair thiol-damaged proteins), since they have the ability to remove glutathione from proteins (40-42). 
Summing up, ROS, intracellular thiols, and glutathionylation play a key role in regulating physiological and cellular processes. They do it by activating or deactivating transcription factors and signalling proteins or by increasing their turnover, expression, translocation, or binding to DNA.

Table 1 lists a number of glutathionylated transcription factors and signalling proteins that are involved in normal cell function. Some of them are described in detail in the text.

\section{MOLECULAR INTERACTIONS WITH TRANSCRIPTION FACTORS}

\section{Glutathione synthesis is regulated by glutathionylation}

Glutathione regulates its own cycle (Figure 1) by modifying the nuclear factor (erythroid-derived 2)-like 2 (Nrf2, NFE2L2, p45-related factor 2). This transcription factor protects the cell from oxidative stress by regulating several hundreds of antioxidant genes (16). Nrf2 also controls the transcription of important enzymes in the GSH

Table 1 Glutathionylated proteins and signalling molecules involved in the regulation of cellular processes

\begin{tabular}{|c|c|c|}
\hline \multicolumn{3}{|c|}{ CELL PROCESSES AND REGULATION } \\
\hline Function & Proteins shown to be glutathionylated & References \\
\hline $\begin{array}{l}\text { DNA and gene } \\
\text { regulation, } \\
\text { protein synthesis, } \\
\text { and proteolysis }\end{array}$ & $\begin{array}{l}\text { H3 (histone } 3 \text { ); 20s } \boldsymbol{\alpha} \text { (proteosome subunit); HSP90ß (heat shock protein 90); } \\
\text { HSP70 (heat shock protein 70); HSP60 (heat shock protein 60); sirtuin 1: NAD- } \\
\text { dependent acetylase } 1\end{array}$ & $\begin{array}{l}9,16,69 \\
157,206 \\
207\end{array}$ \\
\hline $\begin{array}{l}\text { Cell signalling } \\
\text { channel proteins }\end{array}$ & $\begin{array}{l}\mathbf{1 4 - 3 - 3 \gamma} \mathbf{S 1 0 0} \text { (S100 Calcium binding protein A1); SERCA (sarco/endoplasmic } \\
\text { reticulum } \mathrm{Ca}^{2+} \text {-ATPase ); RyR1 and } \mathbf{2} \text { (Ryanodine receptor type1); CFTR (cystic } \\
\text { fibrosis transmembrane conductance regulator); } \mathbf{N a H}^{+} \text {transporter; NaK-ATPase }\end{array}$ & 9,16 \\
\hline
\end{tabular}

MKP-1(mitogen activated protein kinase1) on $\mathrm{Cys}^{258}$ glutathionylation diminishes phosphorylation; MAPK c(X)5-Rmotif; AMPK (5' AMP-activated protein kinase) glutathionylated during low GSH levels; PTEN (phosphatase and tensin homolog) glutathionylation inhibits PTENs phosphorylation of PIP3 (phosphoinositol 3 phosphate) lowering cellular phophoinositol-biphosphate; PP2A (protein phosphatase 2); Src on $\mathrm{Cys}^{277}$; PKC $\boldsymbol{\alpha}$ (protein kinase C alpha) and PKC $\boldsymbol{\delta}$ glutathionylation on $\mathrm{Cys}^{499}$ inhibits enzyme activity decrease of cell growth and Transduction proliferation; c-jun GSNO activated can be glutathionylated during low GSSG and regulatory concentrations on $\mathrm{Cys}^{269}$ decreases DNA binding and inhibit proliferation; MEKK1 proteins (Mitogen-activated protein kinase) $\mathrm{Cys}^{1238}$ glutathionylation inhibits activity and cell proliferation while increase apoptosis; PTP1ß (protein tyrosine phosphatase 1ß) glutathionylation on $\mathrm{Cys}^{215}$ activate proliferation; P50 glutathionylation on $\mathrm{Cys}^{62}$ inhibits proliferation; caspase 1; caspase 8; procaspase 3 glutathionylation inhibits apoptosis, deglutathionylation promotes apoptosis; Ras possibly increase in proliferation while glutathionylationated on $\mathrm{Cys}^{118}$; Fas: glutathionylation on $\mathrm{Cys}^{294}$ increases apoptosis; PKA (protein kinase A); Ask1, RIP1; RIP 3; DAPDH, SSH1L (cofilin-phosphatase slingshot-1L); PKM (pyruvate kinase muscle isoenzyme).

\begin{tabular}{|c|c|c|}
\hline $\begin{array}{l}\text { Intracellular } \\
\text { redox status } \\
\text { regulation }\end{array}$ & $\begin{array}{l}\text { TRX (thioredoxin) glutathionylation on } \mathrm{Cys}^{72} \text { abolishes the enzyme ability to } \\
\text { catalyse disulfide reductase activity; Grx (glutaredoxin) by deglutathionating } \\
\text { proteins Grx binds GSH to itself, glutathionylated on } \mathrm{Cys}^{22} \text {; GST } \boldsymbol{\pi} \text { and } \boldsymbol{\omega} \text { bind } \\
\text { glutathione on } \mathrm{Cys}^{44} \text { and } \mathrm{Cys}^{101} \text { while transferring it on other proteins; GPRX } \\
\text { peroxiredoxines. }\end{array}$ & $\begin{array}{l}8,26,53 \\
158\end{array}$ \\
\hline $\begin{array}{l}\mathrm{NO} \text { and GSH-NO } \\
\text { signalling }\end{array}$ & eNOS (endothelial NO synthetase) & $\begin{array}{l}16,164,168 \\
175,177 \\
179\end{array}$ \\
\hline $\begin{array}{l}\text { Leukotrienes and } \\
\text { prostaglandins }\end{array}$ & mPGES & $\begin{array}{l}108,102 \\
130 \\
131 ; 134 ; 135\end{array}$ \\
\hline $\begin{array}{l}\text { Transcriptional } \\
\text { factors and gene } \\
\text { expression }\end{array}$ & $\begin{array}{l}\text { NFкB; Nrf2; AP-1; IкB through IKK glutathionylation on Cys }{ }^{179} \text { inhibits } \\
\text { proliferation; HIF-1; STAT3 glutathionylated on } \mathrm{Cys}^{418,428,468} \text { inhibits proliferation. }\end{array}$ & $\begin{array}{l}16,29,61 \\
62,208,217\end{array}$ \\
\hline
\end{tabular}


pathways and of the cystine/glutamate exchange transporter protein, which maintains intracellular GSH levels through cystine intake. Normally, the intake of extracellular GSH by the cell is low and occurs through GSH transporters (17, 43-45). Cystine serves as a substrate for the cystineglutamate antiporter. This transport system, which is highly specific for cystine and glutamate, increases the concentration of cystine inside the cell. In this system, the anionic form of cystine is transported in exchange for glutamate. Cystine is quickly reduced to cysteine (46). Therefore, beside the anti-inflammatory function (discussed in sections below), Nrf2 confers greater redox potential and resistance to oxidative stress $(47,48)$.

Oxidative stress is a major activation signal for Nrf2 to dissociate from the complex it forms with its inhibitor, the Kelch-like ECH-associated protein 1 (Keap1) (16) (Figure 1). Keap1 subunit is glutathionylated, and GSH regulates its inhibiting activity. Following the dissociation, the Nrf2 subunit translocates to the cell nucleus and binds to the antioxidant-response element (ARE) in the promoter of target genes coding for antioxidant enzymes such as glutathione peroxidase-2 (GPX2), GST, haeme-oxygenase-1 (HO-1, EC 1.14.99.3), nicotinamide adenine dinucleotide phosphate oxidase (NADPH) : quinone reductase (EC 1.6.5.5), and aldo-keto reductase (49-51).

There where the Nrf2 pathway is impaired, such cells have low GSH concentrations and are highly prone to oxidative damage. Nrf2 signalling is also regulated by other posttranslational, transcriptional, translational, and epigenetic mechanisms, other signal proteins (e.g. p62, p21, and IQ motif-containing GTPase-activating protein) (45), and even hormones such as aldosterone (52). Another important regulator of the Nrf2/Keap1 complex is the thioreductase system, more specifically the selenoprotein thioredoxin reductase 1 (TRXR1, EC 1.8.1.9), a highly reactive enzyme.

Thus, beside glutathionylation, TRX pathways have a vital role in thiol and disulphide regulation of protein activation in the cells $(40,53)$. The GSH system and TRX are two distinct pathways with complementary actions (54). Glutathionylation regulating Keap1 works as a positive feedback loop. For example, the GSTP enzyme is regulated at the transcriptional level by Nrf2. When the cell is under oxidative stress, GSTP stimulates glutathionylation of Keap1 with GSH. This, in turn, activates Nrf2 and consequently increases the expression of GSTP (55). With a few exceptions, this is the general scheme of regulatory loop in most cells.

In addition, Nrf2 directly induces the transcription of glutamate cysteine ligase (GCL, EC 6.3.2.2) and GSH synthase (GSS, EC 6.3.2.3), two ATP-dependent enzymes responsible for de novo GSH synthesis in the cytoplasm (51). GCL limits the rate of GSH biosynthesis. It is a holoenzyme consisting of a glutamate cysteine ligase catalytic (GCLC) subunit and a regulatory glutamate cysteine ligase modifier (GCLM) subunit (56). Redox imbalance and accumulation of oxygen radicals trigger GCLC and GCLM expression, which results in elevated GCL activity (Figure 1) and, consequently, higher GSH levels $(16,24,57)$.

\section{How glutathionylation regulates the $N F-\kappa B$ and $A P-1$ signalling pathways}

Beside Nrf2, GCL transcription is also regulated by other redox-sensitive transcription factors, such as the nuclear factor kappa B (NF- $\mathrm{B}$, a homo- and heterodimer of subunit proteins p50, p52, p65, Rel-B, and C-Rel) or activator protein 1 (AP-1). These two transcriptional factors, therefore, affect cellular GSH levels as well (Figure 1). NF- $\kappa$ B stimulates GCLC and GCLM transcription, the first by binding to the $g c l c$ promoter and the second indirectly, by activating AP-1, which, in turn, activates the $\mathrm{gclm}$ promoter (16, 58-60).

The effects of GSH on NF- $\kappa \mathrm{B}$ are distinctly different between the cytoplasm and the nucleus (Figure 1). In the cytoplasm, NF- $\kappa \mathrm{B}$ forms a complex with an inactive, nonDNA-binding $\kappa \mathrm{B}$ inhibitor $(\mathrm{I} \kappa \mathrm{B})$ which cannot enter the nucleus (Figure 1). The key step in NF- $\kappa \mathrm{B}$ activation is the detachment of I $\mathrm{KB}$ from the heterodimer as a consequence of its ubiquitination and phosphorylation through the action of IкB-kinase (EC 2.7.11.10) and protein kinases (such as protein kinase $\mathrm{C}$; PKC; EC 2.7.11.13). When the dissociated $\mathrm{I} \kappa \mathrm{B}$ is ubiquitinated and degraded in the proteasome (Table 1 ), activated NF- $\kappa B$ moves to the nucleus and binds to DNA response elements in the enhancer and promoter regions of genes $(16,28,61-67)$. Glutathionylation occurs at the NF$\kappa \mathrm{B}$ p65 and p50 subunits and at the IкB kinase (66-68) and S20 subunit of proteasome that degrades the dissociated $\mathrm{I} \kappa \mathrm{B}$ subunit (69). In the cytoplasm, NF- $\kappa \mathrm{B}$ activity is either enhanced by GSH depletion or inhibited by exposure to a reactive chemical through Cys modification by covalent binding $(29,70)$. Experiments show that oxidants such as diamide, which oxidise GSH, lead to the accumulation of

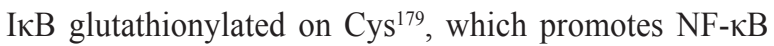
release (70). In contrast, high thiol levels and GSH might inactivate NF- $\mathrm{KB}$ by scavenging the oxidants needed to activate the enzymes involved in NF- $\kappa \mathrm{B}$ activation. Moreover, high GSH levels block protein kinase folding and consequently the phosphorylation of the I $\mathrm{I} B / \mathrm{NF}-\kappa \mathrm{B}$ complex needed for the activated $N F-\kappa B$ to reach the nucleus $(7,16,61)$.

In the nucleus, GSH has the opposite function from the one in the cytoplasm (Figure 1). When NF- $\mathrm{KB}$ is translocated to the nucleus, GSH increases the binding of NF- $\kappa \mathrm{B}$ to DNA. To do that, NF- $\mathrm{BB}$ must be in its reduced form (71). Beside GSH, many other gene products activate NF- $\kappa$ B through the feedback loop, such as interleukins (IL-1 $\beta$, IL-6, IL-8) and tumour necrosis factor alpha (TNF- $\alpha$ ) (72), which participate in the pathogenesis of several inflammatory/immunomediated diseases. Glutathionylation regulates response in many cell types, including $\mathrm{B}$ and $\mathrm{T}$ 


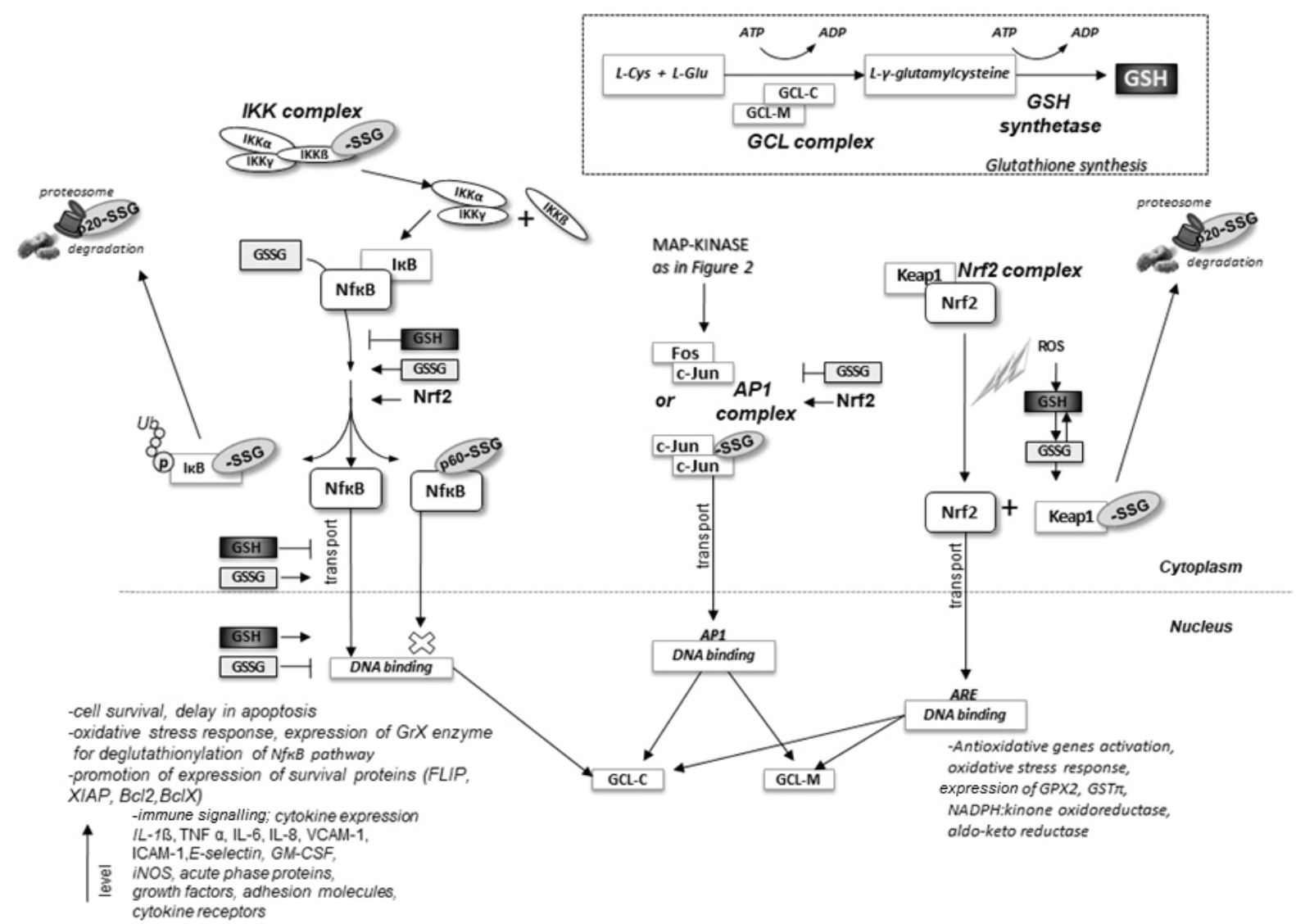

Figure 1 Biosynthesis of glutathione is regulated by Nrf2 through $N f-\kappa B$ and AP1 signalling pathways

ROS - reactive oxygen species; GSH - reduced glutathione; GSSG - oxidised glutathione, glutathione disulphide; GST - glutathione transferase; -SSG - glutathione conjugate through disulphide bridges; Nrf2 - nuclear factor (erythroid-derived 2)-like 2 (NFE2L2);

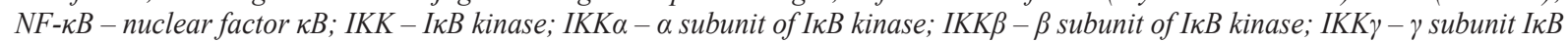
kinase; I $\kappa B$-inhibitor of $\kappa B$; L-Cys - L-cysteine; L-Glu-L-glutamate; GCL-glutamate-cysteine ligase; IL-interleukin; VCAM1 - vascular cell adhesion molecule 1; ICAM1 - intercellular adhesion molecule 1; Keap1-Kelch-like ECH-associated protein 1; MAP kinase - mitogen-activated protein kinase (MAPK); AP-1 - activator protein 1; Fos - fos subunit of AP-1; c-Jun - c-Jun subunit of AP-1; GCLC - glutamate-cysteine ligase catalytic subunit; GCLM - glutamate-cysteine ligase modifier subunit; CFLAR - CASP8 and FADD-like apoptosis regulator; GRX-glutaredoxin; XIAP-X-linked inhibitor of apoptosis; BCL2 - apoptosis regulator Bcl-2; $T N F-\alpha$ - tumour necrosis factor alpha; SELE - selectin E; GM-CSF - granulocyte-macrophage colony-stimulating factor; iNOS inducible nitric oxide synthase; GPx2 - glutathione peroxidase 2; GST $\pi$-glutathione transferase pi

lymphocytes, macrophages, and monocytes (62). For example, NF-kB activated in microglia and macrophages by cytokines, bacterial endotoxins, or other stimuli promotes the expression of several pro-inflammatory proteins, including TNF- $\alpha$, cyclooxygenase 2 (COX-2), and inducible nitric oxide synthase (iNOS) (73).

Even in erythrocytes, NF- $\mathrm{kB}$ and major components of the canonical NF-KB signalling pathway interfere with the antioxidative system. Challenged by its inhibitors, compounds such as Bay 11-7082 and parthenolide, GSH levels drop, and so does erythrocyte survival (74). The examples of responses of NF- $\mathrm{kB}$ to GSH in vivo are numerous and specific $(9,19,35,64)$.

AP-1 is a transcription factor regulating physiological processes, cell growth and proliferation (including tumorigenesis), differentiation, apoptosis, and organogenesis (75-77). It is a complex composed of gene products (Figure
1) from the Jun and Fos proto-oncogene families $(67,71$, 75). They form homodimeric (Jun/Jun) or heterodimeric (Jun/Fos) complexes that bind to DNA $(71,75)$. AP-1 transduces physiological signals from molecules such as cytokines, growth factors, and neurotransmitters to the nucleus (64). Environmental stimuli activate extracellular signal-regulated kinases (ERKs), which, in turn, activate AP-1, including its c-Fos and c-Jun family members (78). The AP-1 Jun/Fos complex binds to the tetradecanoylphorbol13-acetate TPA-responsive element (TRE)/AP-1 on DNA $(8,75,76)$. A "leucine zipper" domain between the Jun and Fos dimers of AP-1 is crucial for binding to TRE. Fos and Jun preserve cysteine residues in the basic motif, which, if oxidised, interferes with the binding of AP-1 to DNA (27). AP-1 gene transcription is activated by the phosphorylation of c-Jun on $\mathrm{Ser}^{63}$ and $\mathrm{Ser}^{73}$ through the activity Jun $\mathrm{N}$-terminal kinase (JNK, also known as mitogen-activated 
protein kinase 8, MAPK8) (64). However, glutathionylation can inhibit JNK $(16,78,79)$.

In contrast, ROS can induce the synthesis, activation, and the translocation of AP-1 $(8,63,67,71,77)$. Studies in vitro have shown that drops in GSH and rises in ROS levels can lead to the oxidation of c-Jun thiols, which promotes c-Jun redox-regulated AP-1 DNA binding activity, whereas an increase in GSSG inhibits c-Jun transcription $(8,16,19$, $80)$. The c-Jun subunit responds to both oxidative and nitrosative stress. Thus, a decrease in the GSH to GSSG ratio or even an increase in $S$-nitrosoglutathione (GSNO) can promote glutathionylation on c-Jun Cys ${ }^{269}$. The c-Jun subunit can also be activated by the formation of disulphide bridges between $\mathrm{Cys}^{320}$ residues. This is an example of how both oxidation mechanisms and disulphide formation on sites specific for S-glutathionylation on Cys residues regulate the DNA-binding of c-Jun (19, 66, 81-83). Glutathionylation of c-Jun promotes DNA binding of AP-1. Unlike other proteins undergoing glutathionylation, c-Jun is a protein that can be glutathionylated under relatively moderate GSSG concentrations (19). Binding of AP-1 can also be enhanced by TRX in cooperation with a nuclear protein known as redox factor 1 (Ref-1), as it promotes Cys transition from reduced to oxidised forms (27). AP-1 to DNA binding is inhibited by GSSG and GSNO in many cell types (19). Some researchers, however, report that AP-1 to DNA binding is stimulated if intracellular GSH is lowered with DL-buthionine-( $S, R)$-sulphoximine (BSO) or if the GSH to GSSG ratio is raised with diamide, like in HepG2 cells. This may partly be due to the redistribution of GSH in the nucleus in addition to the presence of Ref- 1 and TRX $(65,66)$.

In addition to regulating many genes, AP-1 to DNA binding also upregulates the expression of GCL and consequently GSH levels (Figure 1). One example is the increased GSH in the bronchoalveolar lavage fluid (BALF) of chronic cigarette smokers (84), as oxidation probably activates AP-1. However, one hour after acute smoking up to two cigarettes, GSH depletes quickly because of inadequate adaptive increase in antioxidant levels in the epithelial lining fluid of chronic cigarette smokers, insufficient to protect the lung epithelium even when exposure is so short (84).

\section{Glutathione interaction with apoptosis signal proteins}

Evidence collected in recent years shows that a balance between GSH and GSSG is important for apoptosis regulation. Changes in the GSH/GSSG ratios can induce apoptosis through several intracellular signalling pathways (Table 1), but mainly through glutathionylation of specific proteins, as illustrated in Figure 2 (marked as disulphide conjugates, -SSG) $(6,19,85,86)$. They include NF- $\mathrm{BB}$, IKK, AP-1, JNK, mitogen-activated protein kinase 5 (MAP3K5, EC 2.7.11.25), caspases (Cas, EC 3.4.22.553.4.22.64), phosphatidylinositol-3,4,5-trisphosphate 3-phosphatase (PTEN, EC 3.1.3.67), protein kinase C (PKC, EC 2.7.11.13), and the death-inducing signalling complex (DISC). In DISC, glutathionylated is ASK (Figure 2), which determines whether the signal from the extracellular cell surface death receptor (Fas) will proceed to caspase-3 (Cas3, EC 3.4.22.61) in the cytoplasm. Figure 2 also shows the mitochondrial activity and the GSH-dependent BCL2associated $\mathrm{X}$ protein (BAX), which regulates apoptosis activation. Several experimental studies describe BAX as an early step in $\mathrm{H}_{2} \mathrm{O}_{2}$-induced apoptosis $(26,85)$. In them, cells were treated with the tert-butyl hydroperoxide (TBH), which causes redox imbalance in the mitochondria and generation of ROS. Mitochondria lose integrity, release cytochrome c, and activate Cas-9 and Cas-3. Ultimately, Cas-3 glutathionylation will determine whether DNA fragmentation factor subunit alpha (DEFA) will cause DNA fragmentation and apoptotic cell death $(87,88)$. Hansen and Harris (25) showed that cell death is mediated by an increase in cellular GSSG rather than by a decline in GSH. However, during differentiation and embryonic development, necrosis and apoptosis are characterised by GSH decline and oxidising conditions, while during proliferation they are characterised by reducing conditions and higher GSSG.

\section{Glutathione, angiogenesis, and vascularisation}

Hypoxia-induced factor- 1 alpha $(\mathrm{HIF}-1 \alpha)$ is a transcription factor (among those listed in Table 1) that interacts with GSH specifically under ischemic and hypoxic conditions (89). Watanabe et al. (89) have demonstrated that higher ROS levels in ischamic tissues lead to glutathionylation of the $\mathrm{Cys}^{520}$ residue of HIF-1 $\alpha$. In experimental in vitro studies, HIF-1 $\alpha$ was glutathionylated by adding cell-permeable GSSG-ethyl ester or 2-acetylamino-3-[4-(2-acetylamino-2-carboxyethylsulpha nylthiocarbonylamino)phenylthiocarbamoylsulphanyl] propionic acid (2-AAPA), both of which inhibit GSR. GSR inhibition decreases GSH and increases GSSG, promoting glutathionylation on the $\mathrm{Cys}^{520}$ residue of HIF. This glutathionylation on $\mathrm{Cys}^{520}$ can be reversed by activating GLRX1, which then removes GSH from HIF-1 $\alpha$. In another experiment, GLRX1 ablation caused accumulation of stabilised, glutathionylated HIF-1 $\alpha$ in $\mathrm{C} 2 \mathrm{C} 12$ cells. Stabilised HIF-1 $\alpha$ promoted revascularisation by inducing higher vascular endothelial growth factor A (VEGF-A) production. In in vivo experiments, this recovered blood flow and improved ischaemic revascularisation of the muscles after femoral artery ligation (89).

Hughes et al. (39) also found that HIF-1 $\alpha$ is an important factor in macrophage function. Madamanchi and Runge (83) confirmed that, in addition to glutathionylation, the GSH/GSSG balance affects vascularisation indirectly (which can lead to pathological changes of blood vessels) through other complex redox signalling interactions (83). Future experiments will try to answer how can stabilised 


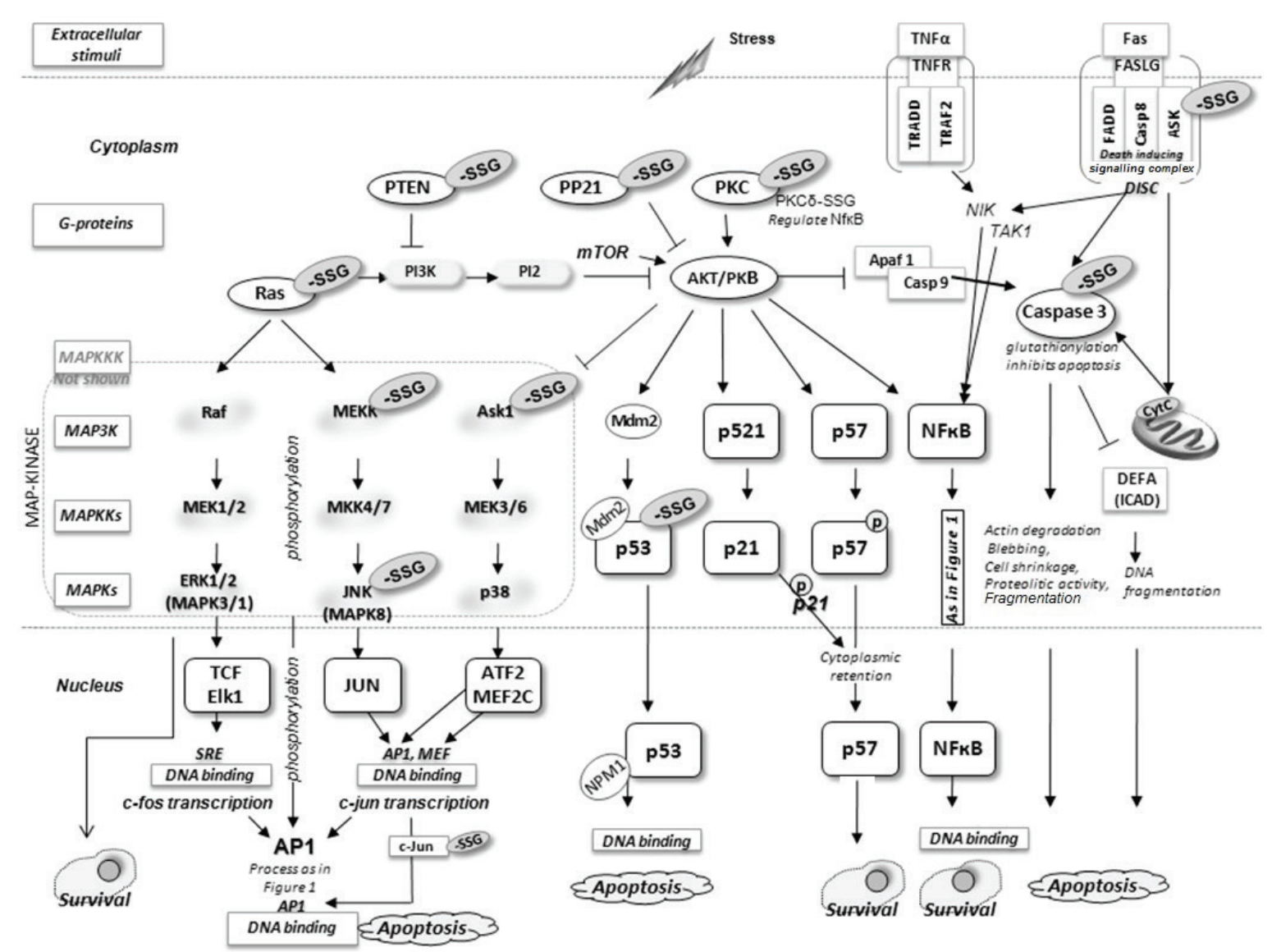

Figure 2 Glutathionylation of signalling proteins and transcription factors involved in pathways regulating cell death or survival -SSG - glutathione conjugate through disulphide bridges; Ras - a small GTP-binding protein GTP-ase); Raf kinase - proto-oncogene serine/threonine-protein kinase; PTEN - phosphatase and tensin homologue; PI3K - phophoinositol 3 kinase; MAPK - mitogenactivated protein kinase; MAPKK - mitogen-activated protein kinase kinase; MEK1/2 - mitogen-activated protein kinase 1 or 2 (MAP2K1/2); ERK 1/2 - extracellular signal-regulated kinases 1 and 2 (MAPK 3/1); MEKK-mitogen-activated protein kinase kinase kinase (MAP3K); MKK - mitogen-activated protein kinase kinase (MAP2K); Ask1 - apoptosis signal-regulating kinase 1 or mitogenactivated protein kinase kinase kinase 5 (MAP3K5); MEKK 3/6 - mitogen-activated protein kinase 3 or 6 (MAP3K3/6); TCF Elk1 ternary complex factor (TCF) ETS domain-containing protein Elk-1; SRE - serum response element of DNA; AP-1 - activator protein 1; PI3K-phosphatidylinositol-4,5-bisphosphate 3-kinase; JNK-janus kinase c-Jun N-terminal kinase or mitogen-activated protein kinase 8 (MAPK8); JUN-c-Jun gene; 533 - tumour suppressor gene p53; ATF2 - activating transcription factor 2; MEF2c-myocytespecific enhancer factor $2 C ; A K T / P K B-A K T 1-R A C$-alpha serine/threonine-protein kinase or protein kinase $B$ (PKB); MDM2 - mouse double minute 2 oncoprotein; TNF - tumour necrosis factor alpha; TNFR-tumour necrosis factor receptor superfamily $1 A$ and $1 B$ (TNFRSF1A/1B); TRADD - tumour necrosis factor receptor type 1-associated DEATH domain protein; TRAF - TNF receptor-associated factor 2; mTOR - mechanistic target of rapamycin; APAF1 - apoptotic peptidase activating factor 1; Casp 9 - caspase 9; Casp 3caspase 3; FAS - Fas cell surface death receptor; FasR - FAS receptor or apoptosis antigen 1 (APO-1 or APT); FADD - Fas-associated protein with death domain synonym MORT1; FASLG - Fas ligand; DEFA - DNA fragmentation factor subunit alpha (also known as ICAD); NPM1 - nucleophosmin 1

(glutathionylated) HIF-1 $\alpha$ proteins affect tumour vascularisation and help treatment.

$$
\text { p53 }
$$

Under oxidative stress, the activity of p53 is governed by S-glutathionylation (Figure 2). This is when GSHadducts inhibit p53 on the Cys residues in the proximal DNA-binding domain (90). In stress, most posttranslational modifications on p53 enhance its transcriptional activity, which, in turn, triggers the cell cycle checkpoints. S-glutathionylation on Cys ${ }^{141}$ of p53 interferes with p53 dimerisation, which inhibits p53 to DNA binding and interferes with its main tumour suppressing function but also with its inhibition of angiogenesis, its role in apoptosis, and genomic stability.

In its anti-cancer role, $\mathrm{p} 53$ activates DNA repair proteins and arrests cell growth by holding the cell cycle at the G1/S phase for as long as necessary for the DNA repair proteins to fix the damage. Only then will the cell cycle continue $(83,90)$.

GSH interaction is associated with yet another important protein, nucleophosmin (NPM1) (Figure 2). NPM1 is a histone chaperone (Table 1), important in the transport and synthesis of ribosome and nuclear acid stability. Under normal conditions, NPM1 is bound to RNA and partly to DNA. Cellular stress triggers its dissociation from nucleolar 
nucleic acids and translocation from the nucleus to the nucleolus, which activates p53 to DNA binding and p53dependent apoptosis. Using live-cell imaging and redox biosensors, Yang et al. (91) have demonstrated that NPM1 undergoes glutathionylation on $\mathrm{Cys}^{275}$, which triggers its dissociation from nucleolar nucleic acids. In contrast, its mutant protein $\mathrm{C} 275 \mathrm{~S}$ (cys/ser substitution) could not be glutathionylated and remained bound to DNA under nucleolar stress. Among several anti-proliferative compounds interacting with NPM1, the authors identified avrainvillamide, which binds specifically to NPM1 at Cys ${ }^{275}$ and disperses NPM1 into the nucleoplasm. The application of actinomycin D, which binds to glutathione at $\mathrm{Cys}^{275}$, causes a similar effect on NPM1. A recent clinical application of actinomycin D caused substantial remission in patients with acute myeloid leukaemia. This GSH involvement and manipulation with its active binding site on NPM in nucleolar stress sensing may help to develop therapeutic strategies (91).

Another protein involved in GSH metabolism and DNA control by $\mathrm{p} 53$ is the MDM2 oncoprotein, a major negative regulator of the p53 tumour suppressor protein. Riscal et al. (92) showed that MDM2 can regulate amino acid metabolism and redox homeostasis of serine/glycine metabolism and, therefore, GSH recycling in the cell.

\section{Glutathione interactions with signalling and regulatory proteins in metabolic processes}

Important evidence is emerging of GSH regulatory roles in various metabolic states (Table 2), although such research is just emerging in contrast to the research of glutathionylation in the immune system, cell growth, survival, apoptosis, or tumorigenesis.

Adipocytes are major energy depots, and peroxisome proliferator-activated receptor $\gamma(\operatorname{PPAR} \gamma)$ is the major transcription factor controlling the growth and differentiation of adipocytes. This transcription factor is regulated by two signalling molecules: 15-deoxyprostaglandin J2 (15d-PGJ2) and 4-hydroxynonenal (4-HNE), which is a product of lipid peroxidation. Both are conjugated with $\mathrm{GSH}$, which lowers PPAR $\gamma$ activity $(93,94)$. Additionally, obesity-induced insulin resistance is linked to 4-HNE as one of the most abundant lipid aldehydes in adipose tissue. In adipocyte oxidative stress, it is metabolised by glutathione $\mathrm{S}$-transferase A4 (GSTA4) into pro-inflammatory glutathionyl-HNE (GS-HNE) and glutathionyl-1,4-dihydroxynonene (GSDHN). According to a recent discovery by Frohnert et al. (95), this is how adipocyte dysfunction results in tissue inflammation and insulin resistance.

In mitochondria, peroxisome proliferator-activated receptor- $\gamma$ coactivator $1 \alpha$ (PGC-1 $\alpha$ ), MAPK, and sirtuin (for example sirtuin1, Table 1, possibly others too) are regulated by glutathionylation or ROS. Glutathionylation regulates complex I, which increases mitochondrial superoxide anion $\left(\mathrm{O}_{2}^{-}\right)$production. Complex II proteins are continuously glutathionylated. Other mitochondrial proteins, uncoupling proteins (UCP 2 and 3), ATP synthetase, and succinyl-CoAsynthetase are also glutathionylated (16). GSH also binds to coenzyme A : glutathione-disulphide oxidoreductase (EC 1.8.4.3), an important enzyme in the metabolism of amino acids $(7,39,94)$, and to dehydroascorbate reductase [GDOR, also known as glutathione dehydrogenase (ascorbate), EC 1.8.5.1], which reduces dehydroascorbate to ascorbate (7). Table 2 lists other mitochondrial proteins and effects related to glutathionylation, such as mitochondrial fusion.

It is believed that physical inactivity disrupts metabolic and redox homeostasis and eventually leads to ROSassociated diseases (7). There are clear connections between metabolic states and GSH. For example, physical ability in GSH-deficient rats is known to be reduced in half (54). Most of the research on this topic assumes that oxygen is consumed during physical exercise, that GSH is oxidised, and that GSSG tissue levels increase. This GSSG build up, however, upregulates glutathionylation. Exercise enhances GSH levels by inducing GSH synthesis and also by increasing GSH regeneration from GSSG. In other words, high oxygen consumption during physical exercise restores GSH through transcriptional mechanisms explained earlier in the text as well as through the TRX pathways. Animal experiments with exercise suggest that the GSH and TRX pathways are opposite pathways, as TRX-1 activity negatively correlates with GSH (54).

Exercise is also related to angiogenesis, which is regulated by HIF-1 $\alpha$. Increased ROS production through exercise is believed to affect DNA methylation and posttranslational modifications of histone residues, which, in turn, create conditions for heritable epigenetic adaptive chromosomal conditions. Physiological response to exercise is elevated ROS and biochemical imbalance in the muscle tissue, which make muscles contract (54). Creatine kinase $\mathrm{M}$ isoenzyme (CK-M, EC 2.7.3.2), which regenerates ATP in muscles, has been shown to be glutathionylated at $\mathrm{Cys}^{283}$. However, this regulation was investigated only in vitro (16, 18). During muscle contraction, glutathionylation promotes ryanodine receptor (RyR) 1 and 2 activity, which controls the release of $\mathrm{Ca}^{2+}$ into muscle cells. Glutathionylation occurs on $\mathrm{Cys}^{674}$ of the sarcoplasmic reticulum $\mathrm{Ca}^{2+}$ ATPase (SERCA, EC 3.6.3.8), but GSH has also been shown to regulate other endoplasmic reticulum proteins beside SERCA, such as immunoglobulin heavy chain-binding protein $(\mathrm{BiP})$, protein disulphide isomerase (PDI), calnexin, calreticulin, and endoplasmin $(16,18)$.

In metabolic syndrome-related cardiovascular diseases, reduction of plasma and vascular GSH results in increased oxidative stress, which promotes atherosclerosis (96). TNF- $\alpha$ activates NF- $\kappa$ B, which, in turn, upregulates the expression of adhesion molecules on the surface of endothelial cells and vascular smooth muscle cells of blood vessels. By inhibiting mitochondrial electron transport chain activity, TNF- $\alpha$ promotes interaction of electrons with $\mathrm{O}_{2}$ 
Table 2 Glutathionylated proteins involved in the regulation of physiological systems

\begin{tabular}{|c|c|c|}
\hline \multicolumn{3}{|c|}{ PHYSIOLOGICAL SYSTEMS } \\
\hline Function & Proteins shown to be glutathionylated & References \\
\hline Mitochondrial & $\begin{array}{l}\text { MMC I: mammalian mitochondrial complex I glutathionylated under various } \\
\text { conditions) deactivates electron transfer and increases ROS production; }\end{array}$ & \\
\hline $\begin{array}{l}\text { ROS production and ROS } \\
\text { scavenging }\end{array}$ & $\begin{array}{l}\text { MMC II: mammalian mitochondrial complex II glutathionylated increases } \\
\text { activity and decreases ROS production }\end{array}$ & 9,16 \\
\hline
\end{tabular}

\section{Mitochondrial \\ function and integrity \\ ANT: adenine nucleotide translocase on $\mathrm{Cys}^{56}$; mPTP: mitochondrial transport pore protein opens upon glutathionylation; OGC: oxoglutatarate carrier; DIC: dicarboxylate carrier - GSH transport through mitochondrial membrane in liver and kidney; TTC: tricarboxylate carrier - GSH transport through mitochondrial membrane in brain; MFN2: Mitofusin-2 and GSSG binding stimulates mitochondrial fusion}

Mitochondrial

Biochemistry, bioenergetics

ATP5A1: ATP synthetase $\alpha$-subunit isoform 1 on $\mathrm{Cys}^{244}$ and $\mathrm{Cys}^{294}$ in conditions of high glucose; UCP 2: uncoupling protein 2

GAPDH: glyceraldehide 3-phospahate dehydrogenase; ATP5A1: ATP synthetase $\alpha$-subunit isoform 1 ; carbonic anhydrase; haemoglobin; CK:

Energy metabolism and creatine kinase; IDH: isocitrate dehydrogenase; $\boldsymbol{\alpha K G D H : ~} \alpha$-ketoglutarate glycolysis dehydrogenase; PDH: pyruvate dehydrogenase e2 subunit; aconitase; storage and transport of cysteines

\begin{tabular}{lll}
\hline $\begin{array}{l}\text { Cell adhesion, architecture } \\
\text { and movement, muscles }\end{array}$ & $\begin{array}{l}\boldsymbol{\beta} \text {-actin on Cys } \\
\text { myosine; troponin I }\end{array}$ \\
\hline Neural system & Nrf2/Keap & $\begin{array}{l}\text { 9, 16, 214, } \\
215\end{array}$ \\
\hline & Amyloid & 213 \\
\hline Na,K-ATPase & $185-195$ \\
& Parkinson's disease; Huntington's disease; Alzheimer's disease \\
\hline
\end{tabular}

MGST1:microsomal glutathione S-transferase 1; CPLX2: complexin-2;

PBK: lymphokine-activated killer T-cell-originated protein kinase; CPSF6: cleavage and poly adenylation specificity factor subunit 6, PRDX5:

Immune system mitochondrial peroxiredoxin-5; RPLP1: 60S acidic ribosomal protein P1; PRDX3: mitochondrial thioredoxin-dependent peroxide reductase; DSTN: actin-depolymerizing factor; PCBP1: poly(rC)-binding protein 1; EIF5A: eukaryotic translation initiation factor 5A; AKR1C1: aldo-ketoreductase 65,66 , 139,189 , 209,210 family 1 member C1; AKR1C3: aldo-ketoreductase family 1 member C3; MAL: MyD88 adaptor-like $\mathrm{Cys}^{91}$ glutathionylation critical protein in innate immunity; NLRP3 /IL-1及 inflammasome pathway

Monocytes; macrophages; T-lymphocyte function

Cytokine production and immune response
$9,16,19$ 149,150

$7,65,66$,

139,142 , 147 and increases the production of superoxide anion $\left(\mathrm{O}_{2}{ }^{-}\right)(65$, $97)$ and hydrogen peroxide $(79,98)$, which intensify the pathological processes resulting in the activation of inflammatory cells in the adipose tissue, endothelial dysfunction, and atherogenesis in vascular tissues $(72,99)$. Glutathionylation, therefore, plays a complex regulatory role in obesity, metabolic syndrome-related cardiovascular diseases, and diet-induced dyslipidaemia and cholesterolaemia $(83,100)$.
The list of transcription factors and regulatory proteins (101) involving glutathionylation will expand in the future. Table 1 summarises other cellular regulatory proteins that have not been described in more detail in this text, because this review will focus on other signalling molecules such as eicosanoids, cytokines, and nitric oxide (NO) and their relation to glutathione. 


\section{GLUTATHIONE AND EICOSANOIDS}

\section{MAPEG superfamily enzymes and their relation to GSH}

The superfamily of large, membrane-associated proteins in eicosanoid and glutathione metabolism (MAPEG) share structural evolutionary relationship with the cytosolic GST. This superfamily includes enzymes crucial in leukotriene (LT) and prostaglandin (PG) physiology and synthesis, namely leukotriene synthases (LTCS), prostaglandin synthases (PGES), 5-lipoxygenase activating protein (FLAP), and microsomal glutathione S-transferases (MGST 1-3) (102).

Their structural similarity to GST makes glutathione an important cofactor in their activity and in the physiology of eicosanoids. The MAPEG enzymes participate in inflammatory processes and, to a certain extent, in biotransformation and detoxification. However, evidence of their glutathionylation is scarce, because of methodological challenges, since they are membrane-integrated proteins and therefore slightly more complex to isolate and investigate, but new data are being gathered as research methods advance (102).

\section{Leukotrienes (LTS)}

Leukotrienes are fatty acid signalling molecules first found in leukocytes (hence their name). In the synthesis of some of them GSH plays a major role (103). LTs are generally recognised as potent inflammatory factors, particularly activated during inflammation. Their role is to attract certain white blood cells, but also to enhance the action of PGs during reproduction by binding to G-proteincoupled receptors on target cells (104-107). Leukotriene B4 (LTB4), leukotriene C4 (LTC4), and their metabolites leukotriene D4 (LTD4) and E4 (LTE4) stimulate endothelial cell-leukocyte adhesion and chemokine excretion and act as potent neutrophil chemoattractants. They are mainly involved in vascular leakage and epithelial barrier functions (108-110). Cysteinyl LTs (LTC4, LTD4, and LTE4) are crucial mediators of inflammation and inflammatory diseases of the respiratory and cardiovascular systems, such as bronchial asthma (111), allergic reactions $(104,112)$, bronchoconstriction, and neutrophil extravasation (108).

LTs are synthesised through multistep enzymatic pathways (Figure 3 ). Their biosynthesis begins with cytosolic phospholipase A2 (EC 3.1.1.4) mediating the release of arachidonic acid from the cell membrane and converting it to unstable epoxide intermediate, leukotriene

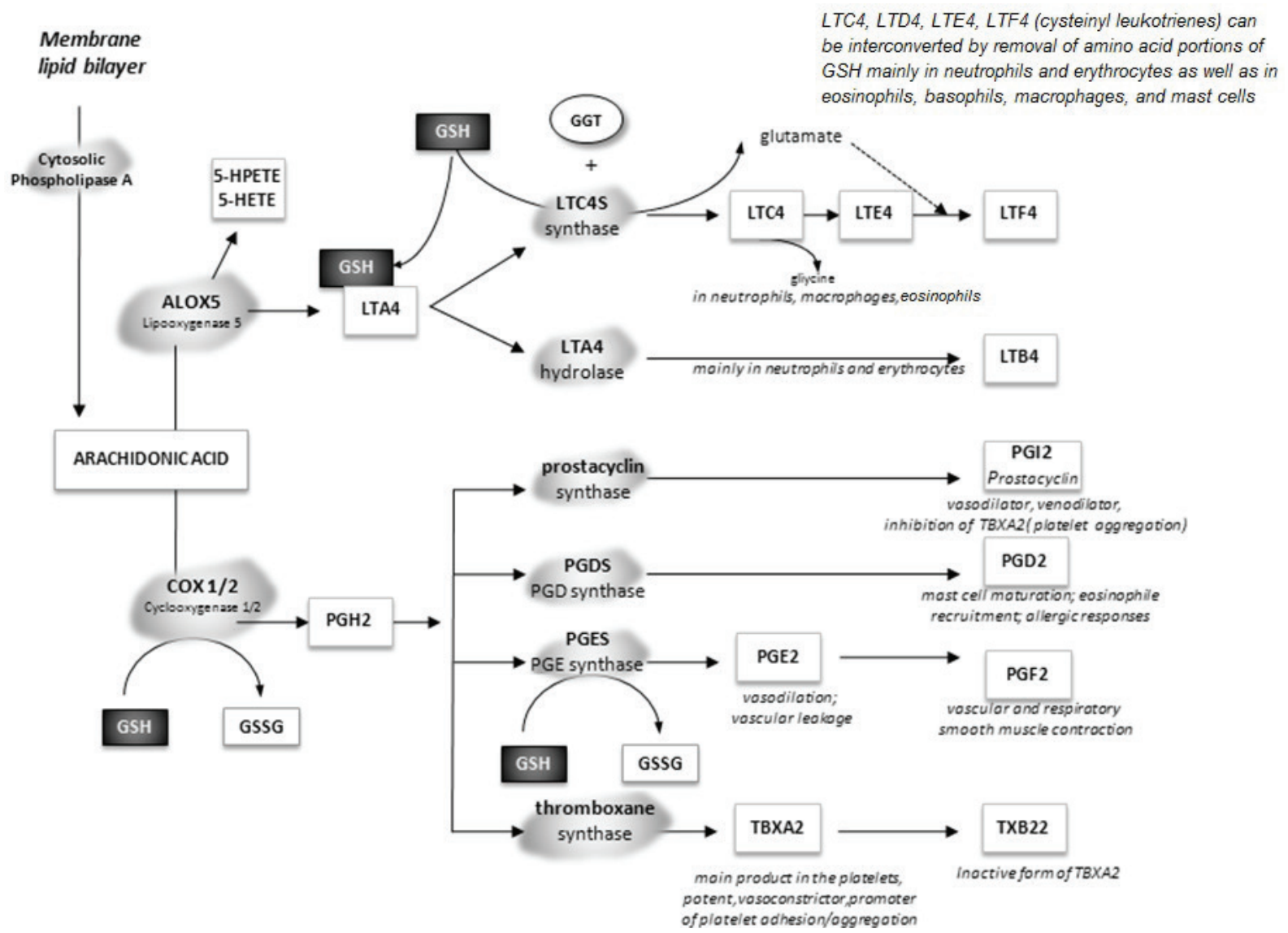

Figure 3 The role of glutathionylation in the synthesis of eicosanoid molecules

5-HPETE - hydroperoxyeicosatetraenoic acid or arachidonic acid 5-hydroperoxide; 5-HETE - 5(S)-hydroxyicosatetraenoic acid; ALOX5 (LOX5) - arachidonate 5-lipoxygenase; COX1/2 - cyclooxygenase 1 or 2, also known as PTGS1/2 - prostaglandin-endoperoxide synthase 1 or 2; LTA4 - leukotriene A4; LTC4 - leukotriene C4; LTE4 - leukotriene E4; LTF4 - leukotriene F4; LTB4 - leukotriene B4; PGI2 - prostaglandin I2; PGD2 - prostaglandin D2; PGF2 - prostaglandin F2; TBXA2 - thromboxan A2 
A4 (LTA4). This intermediate can be transformed to LTB4 by hydrolysis or to LTC4 by conjugation with glutathione. Therefore, LT levels correlate with GSH levels (104, 108, 109, 110). The conjugation of LTA4 with reduced GSSG mediates cysteinyl LT synthesis (111-115) through glutathione S-transferase leukotriene C4 synthase (LTC4S, EC 4.4.1.20) from the MAPEG superfamily to form an intracellular parent compound, the pro-inflammatory LTC4 by adding GSH at C6 of LTA4 $(113,116)$. Synthesised and excreted LTC4 is highly involved in signalling by blood cells and degraded extracellularly by the liver, where it is secreted and metabolised into the biliary system. Bioconversion of LTC4 is the result of the interaction with $\gamma$-glutamyltransferase (GGT, EC 2.3.2.2), which is also the enzyme known to eliminate and degrade glutathione in the kidney, but here it has another, complementary role in inflammation signalling with LTC4 synthase (LTC4S) (116).

\section{Leukotriene C4 synthase}

LTC4S (EC 4.4.1.2) is a $17-\mathrm{kDa}$ integral perinuclear homodimer membrane enzyme. It shows GST activity, strictly specific for LTA4 as a substrate (104, 117-119). LTC4S is similar to other enzymes important for GSH metabolism (covered at the beginning of the text), having the same precursors as the enzymes participating in GSH metabolism (120). It is the only enzyme in haematopoietic cells that utilise GSH and LTA4 to produce LTC4. LTC4S differs from conventional GST by its lack of homology, inability to conjugate GSH to xenobiotics, selectivity for LTA4, differential susceptibility to inhibitors, and inability to bind specific microsomal GST antibodies $(118,120-124$, 144).

Human LTC4S cDNA encodes a protein of 150 amino acids $(104,117)$. The LTC4S monomer has four transmembrane alpha-helices and forms a symmetric trimer as a unit with functional domains across each interface. The structure of the enzyme is complex and has the active site that forms two "U" loop conformations $(111,119)$ on the cytoplasmic side of the membrane. The first hydrophilic loop of LTC4S binds LTA4 at amino acid residue Tyr ${ }^{93}$, and the second hydrophilic loop is essential for GSH conjugation where GSH positions its thiol group on arginine (Arg) on the membrane-enzyme interface (125). At the LTA4 active site, $\mathrm{Arg}^{104}$ activates GSH to produce a thiolate anion that attacks carbon C6 of LTA4. This creates a thioether bond that results in LTA4 glutathionylation (119). The expression of LTC4 synthase is limited to cells of the bone-marrow lineage. In other tissues, LTC4 synthesis is possible with microsomal GSH S transferase-II (MGST-II) when LTC4 synthase is not expressed, such as in the liver and endothelial cells (123). In such tissues LTC4 can be formed through the transcellular metabolism of LTA4, where GSH conjugates to LTA4 to form LTC4 through the MGST2 and MGST3 enzymes (104).
A recently synthesised nanomolar inhibitor of LTC4S glutathionylation, the so called TK04, will be a useful tool in future pharmacological research of GSH/LTC4S interactions and modulation of inflammatory signalling through glutathionylation in blood cells (110).

\section{Prostaglandins}

Figure 3 illustrates the involvement of glutathione in PG metabolism. PGs are biologically active derivatives of arachidonic acid and other polyunsaturated fatty acids. Prostaglandin E2 (PGE2) is expressed in inflammation, vasodilation, and vascular leakage; prostaglandin D2 (PGD2) in mast cell maturation, eosinophil recruitment, and allergic responses; prostaglandin F2 (PGF2) in vascular and respiratory smooth muscle contraction; and prostaglandin I2 (PGI2) in platelet inhibition (103, 108, 126).

The biosynthesis of PG is initiated by the release of arachidonic acid from membrane phospholipids, similar to LT metabolism described above $(108,126)$. It involves oxygenation and cyclisation to an unstable endoperoxide intermediate, prostaglandin G2 (PGG2). Subsequent reduction of $\mathrm{C} 5$ hydroperoxide moiety of PGG2 yields prostaglandin $\mathrm{H} 2$ ( $\mathrm{PGH} 2)$. This reaction is catalysed by cyclooxygenases [COX, aka prostaglandin-endoperoxide synthase (PTGS), EC 1.14.99.1], which come in two forms: the constitutive type COX-1 and the induced type COX-2. Both are indirectly controlled by GSH $(103,108)$. COX-2 is produced in fibroblasts, macrophages, and epithelial cells in response to external chemicals or IL-1 $\beta$ and TNF $\alpha$, which indirectly control PGE2 production.

Prostaglandin E synthase (PGES, EC 5.3.99.3) also needs reduced GSH to convert the endoperoxide group of PGH2 into the 9-keto-11-hydroxy moiety of PGE2. If GSH is not available, there is no PGE2, as demonstrated with A549 cells, whose microsomal fractions containing enzymes for PG synthesis were incubated without GSH $(102,108)$.

\section{Prostaglandin E2 synthases}

There are three types of PGES (EC 5.3.99.3): two microsomal (mPGES1 and mPGES2) and one cytosolic (cPGES aka PGES3). These enzymes have different origin, different physiological properties, different cell localisation, regulation, and catalytic mechanisms, yet they are all involved in the synthesis of the same PG $(127,128)$. Earlier it was believed that mPGES2 was glutathione-independent, in contrast to the rest of the PGESs, but recent research has confirmed that mPGES2 binding activity is possible only in the presence of glutathione (101).

As for mPGES1, it comes from the GSH-dependent MAPEG superfamily and is functionally linked to COX-1 in basal PGE2 and COX-2 in delayed PGE2 synthesis (129133). It is highly expressed in the brain, heart, muscle, kidney, and liver (103). Although mPGES1 is closely related 
to MGST1 (38\% homology), it is unable to catalyse the conversion of PGH2 to PGE2, and the requirement for GSH is the only functional similarity between the two (131). The enzyme is homotrimeric in structure, and the trimer contains four helix bundles which traverse the microsomal membrane (131-135). It catalyses PGE2 in inflammation and pain, participates in cancer cell proliferation and tumour growth, and even participates in detoxification. Inhibiting its activity could significantly reduce hypertension, thrombosis, and myocardial damage compared to the inhibition of COX-2. Pharmaceuticals could target its active site for glutathione binding (136-138).

The third prostaglandin synthase, the cPGES is a GSHdependent enzyme, expressed constitutively in a wide variety of tissues. It is linked to COX-1 and associated with the heat shock protein 90 (Hsp90) in immediate PG production $(129,130)$.

An important prostaglandin production regulator is the transcription factor Nrf2 (described earlier). It induces the transcription of peroxiredoxins 1 and 6 (PRDX1 and PRDX6) and of lipocalin-type prostaglandin D synthase (L-PGDS, EC 5.3.99.2). PRDX1 and PRDX6 protect cells against oxidative stress, but when produced in excessive amounts (thanks to Nrf2), they boost the synthesis of PGE2 and PGD2 (127). Again, the whole pathway is a loop, since PRDX1 binds Toll-like receptor 4, which reversibly induces NF- $\kappa B$ activation, and its accumulation stimulates COX2 and $\mathrm{mPGES} 1$ expression. The end result is more PGs, as described above.

Furthermore, activated MAPKs, p38, and ERK, which are regulated by GSH (Figure 2), additionally phosphorylate PRDX6, activating the synthesis of PGD2. PGD2 and its metabolite $1515 \mathrm{~d}-\mathrm{PGJ} 2$ reactivate $\mathrm{Nrf} 2$ in a positive feedback loop for further synthesis.

\section{GSH AND REGULATORY AND SIGNALLING MOLECULES IN THE IMMUNE SYSTEM}

Apart from eicosanoids, inflammation is regulated by cytokines (interleukins for signalling between leukocytes, chemokines for inducing cell chemotaxis, and interferons for antiviral effects), whose release varies with the type of cell (127).

The sources of ROS and oxidative stress on the immune system can either be internal, i.e. the immune cells (macrophages, neutrophils, and eosinophils) and immune system components (cytokines) or external, i.e. a variety of pathological and toxic states that affect the immune cells. Cells of the immune system contain high levels of polyunsaturated fatty acids and are highly vulnerable to the damaging effects of free radicals. The resulting lipid peroxides act as oxidative stress generators (2). Regardless of the source, the intracellular redox state has a key function in regulating inflammatory response (139-141). ROS activates multiple stress kinase pathways and redoxsensitive transcription factors, including the aforementioned NF- $\mathrm{kB}$ and AP-1. ROS also modulates cytokine production, peptide hormones, and immunoregulators $(92,142)$. Shifts in the GSH/GSSG balance (GSH decrease) during inflammation regulate cytokine production and immune response by activating different types of cells. However, if tissue GSH levels stay low for a long time, immune response may fail $(61,67,142)$.

Several in vitro and in vivo studies have shown that GSH and its precursors downregulate cytokine synthesis, activation, and downstream processes. In lung cells they do it by inhibiting NF- $\mathrm{NB}$ activation and promoting the formation of a NF- $\kappa \mathrm{B} /$ disulphide complex or by directly inhibiting DNA binding $(23,39,142-145)$. Stimulation with lipopolysaccharides (LPS) increases the glutathionylation of IKK $\beta$. Also, experimental silencing RNA (siRNA)mediated knock-down of GSTP decreases the levels of the IKK $\beta$-SSG complex and promotes NF- $\kappa \mathrm{B}$ nuclear translocation, transcriptional activity, and pro-inflammatory cytokine production in response to LPS. LPS-induced NF$\kappa \mathrm{B}$ transcriptional activity and pro-inflammatory cytokine production can also be induced pharmacologically by TLK117, an isotype-selective inhibitor of GSTP (145). This interference is considered a promising target pathway for drug development and strategies to reduce oxidative stressinduced inflammation (146).

On the other hand, cytokines, which themselves are mediators of oxidative stress, disturb the redox equilibrium and affect GSH/GSSG shuttling and recycling (142). Both IKK $\alpha$ and $\beta$ of the NF- $\kappa$ B have been found in the nucleus, but only IKK $\alpha$ is believed to be involved in cytoplasmnuclear shuttling in response to cytokine stimulation. Cytokines TNF $\alpha$, IL-1, and IL-6 can also cause oxidative stress, which, in turn, triggers the activation of NF- $\kappa \mathrm{B}(68)$.

Leukocytes are particularly sensitive to redox changes and changes in GSH levels (147-150). The immune response starts with the activation of monocytes, macrophages, and antigen-presenting cells (APC). Complex regulations of elevated ROS, thiol modifications, disturbances of the redox-sensitive signalling pathways, and protein glutathionylation lead to macrophage polarisation, foam cell formation, monocyte transmigration, and macrophage cell death (9).

Peroxiredoxin 2 (PRDX2) is an antioxidant enzyme activated by redox-dependent inflammatory mediators that promotes glutathionylation and controls cytokine-induced peroxide levels in macrophages. As it possesses inflammatory signal properties, PRDX2 stimulates macrophages to produce and excrete TNF $\alpha$ (151). PRDX2 and some other glutathionylated proteins are excreted in vitro in LPSstimulated macrophages. TRXs are induced as well. PRDX2 and TRX from macrophages change the redox status of cell surface receptors and induce inflammatory response. This mechanism is being investigated as a pharmacological target for chronic inflammatory diseases (151). 
In macrophages and other APCs, GSH is necessary for antigen unfolding (processing for presentation). As it forms disulphide bonds with the antigen, its levels determine which type of cytokines and other regulatory mediators will be secreted, which, in turn, will determine which type of T cell will be activated $(2,7,39,88,152)$. In other words, the cellular response of the immune system will depend on GSH levels in macrophages and APCs (140).

GSH status will also determine a number of $\mathrm{T}$ cell functions. A decrease in or complete lack of GSH in APCs induces cytokine types that inhibit cytotoxic T lymphocytes $(\mathrm{CD} 8+)$ and affect the proliferation of CD16+ NK cells. At the same time, cytokines will promote CD4+ cell activity $(7,88,153)$. GSH can stimulate cytokines that induce CD4+ $\mathrm{T}$ lymphocytes apoptosis (7). How essential GSH is for T lymphocyte proliferation has been demonstrated by several studies $(2,152,154)$, in which intracellular GSH was elevated or depleted with buthionine sulfoximine (BSO). At low GSH levels, human $\mathrm{T}$ lymphocytes did not proliferate after treatment with mitogenic lectins. Increased GSH levels (with 2-oxothiazolidine-4-carboxylate and 2-mercaptoethanol) enhanced mitogenic response by increasing IL-1 and IL-2 production and lymphocyte proliferation or by decreasing the production of the inflammatory mediators PGE and LTB4 $(2,7,67,152,156$, 157).

Several immune functions relevant to HIV-1 infection depend on adequate intracellular GSH levels, such as the activation of natural killer cells, T-lymphocyte-mediated cell death, and lymphocyte activation by mitogens (158). During HIV-1 infection, oxidised GSH in CD4+ lymphocytes increases significantly and disturbs their redox status (158). It has been demonstrated that TNF- $\alpha$ promotes HIV transcription via activation of the transcription factor NF$\kappa \mathrm{B}$. There were even attempts to improve the immunological status by administering $N$-acetylcysteine to HIV patients to raise their GSH levels. The maintenance of the thiol/oxidant balance, therefore, appears to be crucial for the protection against the toxic effects of TNF- $\alpha$ or other inflammatory cytokines $(61,67)$.

However, despite the general opinion that interleukins are not directly glutathionylated, some integrins are, such as the leukocyte very late antigen-4 (VLA-4, $\alpha^{4} \beta^{1}$ ), which binds to the vascular cell adhesion molecule-1 (VCAM-1) and mucosal addressing cell adhesion molecule-1 (MadCAM-1). This binding is essential for the homing and recruitment of leukocytes and mobilisation of progenitor cells. In vitro glutathionylation of this integrin decreased its binding to VCAM-1 and decreased cell rolling on VCAM-1-coated flow chambers (144). The intercellular adhesion molecule 1 (ICAM-1), also known as cluster of differentiation 54 (CD54), is transcriptionally regulated by $\mathrm{NF}-\kappa \mathrm{B}$ and thus indirectly controlled by glutathionylation. It is a primary inflammatory marker that promotes tight adherence of leukocyte integrins to endothelial cells, which is an essential step in leukocyte extravasation. In human pulmonary aortic endothelial cells, ICAM-1 glutathionylation is additionally augmented by TNF- $\alpha$ (159-161), which promotes the expression of ICAM-1 on the cell surface and monocyte adhesion. GRx-mediated de-glutathionylation of ICAM-1 has the opposite effect. Therapeutic application of glutathionylation of ICAM could affect its binding to leukocyte integrins (144).

\section{NITRIC OXIDE (NO), GSNO FORMATION, AND THE ROLES OF GSNO}

NO is a pleiotropic physiological regulator of diverse functions in the cardiovascular, neuromuscular, neurological, genitourinary, gastrointestinal, and renal tissue $(99,162)$. Intracellular GSH determines the sensitivity of certain cell types to NO and its derivatives (163). One such derivative of NO and superoxide $\left(\mathrm{O}_{2}{ }^{-}\right)$is the reactive nitrogen species (RNS), a family of radical molecules catalysed by nitric oxide synthase 2 (NOS2, EC 1.14.13.39) and NADPH oxidase, respectively. With ROS, it constitutes the free radical species in the organism (ROS/RNS) (164).

Cell NO is produced by catalytic conversion of arginine to citrulline by specific NOSs, which take three isoforms: neuronal (nNOS), inducible (iNOS), and endothelial (eNOS), each encoded by its own, highly distinct gene (77). The endothelial form is glutathionylated through GLRX1 to generate mesenteric nitric oxide (165).

NO is also produced in large amounts by cytokineactivated macrophages and monocytes via iNOS, which makes NO an effective tumour-killing cytotoxic agent (77). Figures 4 and 5 illustrate the interactions between different NO adducts and GSH during oxidative stress. As a free radical, NO contains one unpaired electron, which makes it unstable compared to many other chemical species (although it is mildly reactive compared to ROS) (164).

$\mathrm{NO}$ is a mild oxidant and reductant (165). Low and high concentrations of NO have different roles. At low concentrations it behaves as a signalling molecule in many physiological processes, such as modulation of the synaptic and non-synaptic communication between neurons in the brain tissue. At high concentrations it can cause neural cell damage, inflammation, and death, which may lead to neurodegeneration and memory loss (151). High levels of NO produced by inflammatory cells can damage DNA, RNA, lipids, and proteins, causing amplified mutations and changes in enzyme and protein function, such as those seen in carcinogenesis.

RNS are involved in numerous, potentially carcinogenic events; they may trigger lipid peroxidation, induce transversion mutations and DNA strand breaks, disturb the mitochondrial respiratory chain, and affect protein phosphorylation by nitrosylating tyrosine residues such as p53 (77, 166-168). However, beside its radical and damaging effects, $S$-nitrosylation (a covalent attachment of a nitrogen monoxide group to the thiol side chain of 
cysteine) is another redox-based physiological regulation and posttranslational modification of the signalling proteins, just like glutathionylation.

Increased ROS concentrations reduce the amount of bioactive NO, because it reacts with superoxide anion, which results in chemical inactivation and the formation of a highly reactive and toxic peroxynitrite $\left(\mathrm{ONOO}^{-}\right)$with a half-life of less than one second (166). Susceptibility to NO and $\mathrm{ONOO}^{-}$depends on factors such as intracellular glutathione and cellular stress resistance signalling pathways. For example, NO enhances the expression of GCL, a rate-limiting GSH synthesis enzyme described earlier in the text. The availability of GSH in situations of oxidative and nitrosative stress is ensured by GSH recycling and biosynthetic pathways (82). Increased GSH concentration then counteracts RNS cytotoxicity (169).

$\mathrm{NO}$ in more reactive RNS such as $\mathrm{N}_{2} \mathrm{O}_{3}$ can also react with sulphhydryls to form a nitrosothiol (RSNO) through $S$-nitrosylation. Such reactions in GSH also form $S$-nitrosoglutathione (GSNO) (168). It has been shown that GSH is readily nitrosylated in vivo to form GSNO, which is produced both in and outside the cell $(162,169-173)$. The formation of GSNO can also occur through a transnitrosation reaction between thiol and nitrosothiol, which is a reaction between a nitrosylated protein and GSH (163).

Peroxynitrite reacts with the sulphhydryl compounds in the cell due to high intracellular free thiol concentrations $(162,171)$. However, the chemistry involved will depend on a number of factors, including $\mathrm{pH}$ and GSH concentrations. At typical physiological GSH concentrations and $\mathrm{pH}$, the reaction between $\mathrm{ONOO}^{-}$and $\mathrm{GSH}$ will predominantly be a two-electron oxidation process leading to GSSG formation. The first step is sulphenic acid (RS-OH), which is then reduced to disulphide with another GSH, which can be recycled by glutathione reductase $(162,165)$. Another possibility is one-electron oxidation involving peroxynitrous acid and/or its derivatives. It produces a thiyl radical (GS*) that will start an oxygen-dependent chain reaction forming a peroxyl radical that will deplete intracellular GSH (162).

However, most research has focused on GSNO. It modulates cellular processes and signalling through $S$-nitrosylation and/or S-glutathionylation (162 -164, 171, 174). These processes modify Cys thiols in animal cell proteins (174), and any defects in these modifications can cause a disease, such as heart or Alzheimer's disease (163, $164,172)$. In physiological conditions, GSNO and other $S$-nitrosothiols are present in blood and brain. In adult rat brain tissue GSNO ranges between 6 and $8 \mu \mathrm{mol} \mathrm{L}^{-1}$, which is $\sim 0.3$ to $0.7 \%$ of the tissue GSH level (172).

Whenever the GSH/GSNO physiological balance is disturbed, such as in GSH depletion, GSNO will be cleaved (Figure 4). Excess GSNO, in turn, is removed through the activity of $S$-nitrosoglutathione reductase (GSNOR, aka alcohol reductase 5, EC 1.2.1.46). The balance appears to determine whether NO will be cytotoxic or cytoprotective (169). Regulation of protein nitrosation is not well

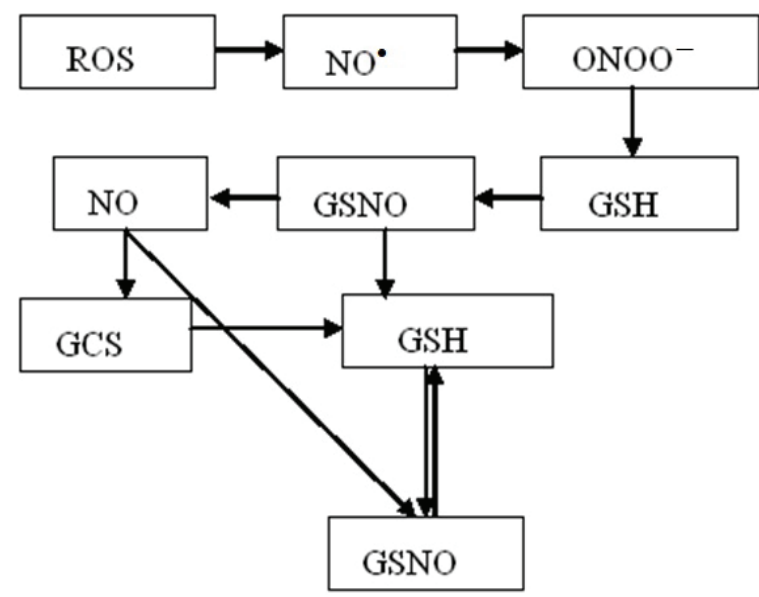

Figure 4 Balance between GSH and GSNO levels during oxidative stress

GSH - reduced glutathione; $R O S$ - reactive oxygen species, NO - nitric oxide; $\mathrm{NO}^{*}$ - nitrosonium ion; $\mathrm{ONOO}^{-}$- peroxynitrite; $G C S$ - $\gamma$-glutamylcysteine synthase; GSNO-S-nitrosoglutathione

understood yet, as NO-dependent events proceed without discernible changes in GSNOR expression (175). GSNO acts as an antioxidant by modifying the redox status, e.g. by increasing GSH or decreasing peroxynitrite levels. It is more stable and approximately 100 times more potent than the classic antioxidant GSH $(163,172,176)$. It can also transport NO in plasma, which prolongs its half-life (168). If cell metabolism needs it, GSNO can serve as a donor of both NO and GSH (169). It also inhibits platelet activation, reduces embolisation in humans (172), and protects neurons $(168,173,177)$ by inhibiting neuron apoptosis and Cas-3 activity. After injuries, it counters inflammation mainly by downregulating NF- $\kappa \mathrm{B}$, adhesion molecules, cytokines, and inducible NOS (iNOS) $(172,173,177)$. In macrophages, thymocytes, lymphocytes, and endothelial cells NO and GSNO can induce apoptosis through various signalling pathways, especially through $S$-nitrosylation/denitrosylation as a reversible redox switch that inhibits inflammatory events $(172,178)$. In in vivo experiments, LPS-challenged rats showed a drop in serum NO, and significant rise in creatinine and BUN, which were successfully countered with GSNO treatment (179). The therapeutic potential of GSNO is yet to be established with the application of new GSNO nanocarriers $(180,181)$ or administration methods suitable for oral applications as target drugs (182).

\section{Glutathionylation in brain and neural tissues}

In recent years, research has focused on glutathionylation and its relation with neurodegenerative diseases and neurophysiology (Table 2), particularly on the major transcription factors and regulatory molecules such as histones (186) in the brain (183-186). Carvalho et al. (55) investigated GSTP glutathionylation of Nrf2 in Parkinson's disease. Speaking of which, Johnson et al. (187) established that GLTRX deficiency exacerbates the neurodegenerative processes. 
In brain cancers, posttranslational glutathionylation on the $\mathrm{Cys}^{145}$ of $\mathrm{O}^{6}$-methylguanine-DNA methyltransferase (MGMT) has promising therapeutic effects (188). MGMT is highly expressed in brain cancer, where it repairs the mutagenic, carcinogenic, and cytotoxic $\mathrm{O}^{6}$-alkylguanine adducts, including those generated by anticancer alkylating agents used in cancer treatment (188).

In Huntington's disease, Cys ${ }^{176 / 178}$ glutathionylation on the $\mathrm{Ca}^{2+}$-permeable transient receptor potential cation channel (TRPC) is increased in the striatum in both transgenic mice and patients. Glutathione-activated TRPC5like currents elevate cytosolic $\mathrm{Ca}^{2+}$, activate calmodulindependent protein kinases and the calpain-caspase pathways, and eventually induce striatal neuronal cell death. This occurs at the same time as the downregulation of the TRPC1 expression, which only adds to the neuronal damage in the striatum cells in Huntington's disease (189).

In Alzheimer's disease, glutathionylation is described as posttranslational control in various cellular processes (190-192). It regulates a key enzyme for ionic homeostasis in cell transduction, $\mathrm{Na}^{+}, \mathrm{K}^{+}$-ATPase $(193,194)$.
Future research will provide more evidence of glutathionylation and redox signalling as important control mechanisms in brain physiology (195).

\section{PROMISING NEW METHODS AND CONCLUSION}

Bioinformatics and various methods developed to detect glutathionylation enable prediction of hundreds of new glutathionylated sites within cells $(9,196-199)$. One such indirect method is the biotin switch assay, which labels oxidation states to identify reversible modifications, S-glutathionylation, $S$-nitrosylation, and conjugated sulphenic acids on proteins. The method is based on the reaction of free thiols with an alkylating agent maleimide. The site is first alkylated, then maleimide removed in a desalting column, and the free thiol can be labelled with a biotin-conjugated alkylating agent such as biotin-HPDP. Such biotin-HPDP labelled (biotinylated) proteins are purified with streptavidin-agarose beads and can be detected with Western blotting and avidin-based detection protocols.

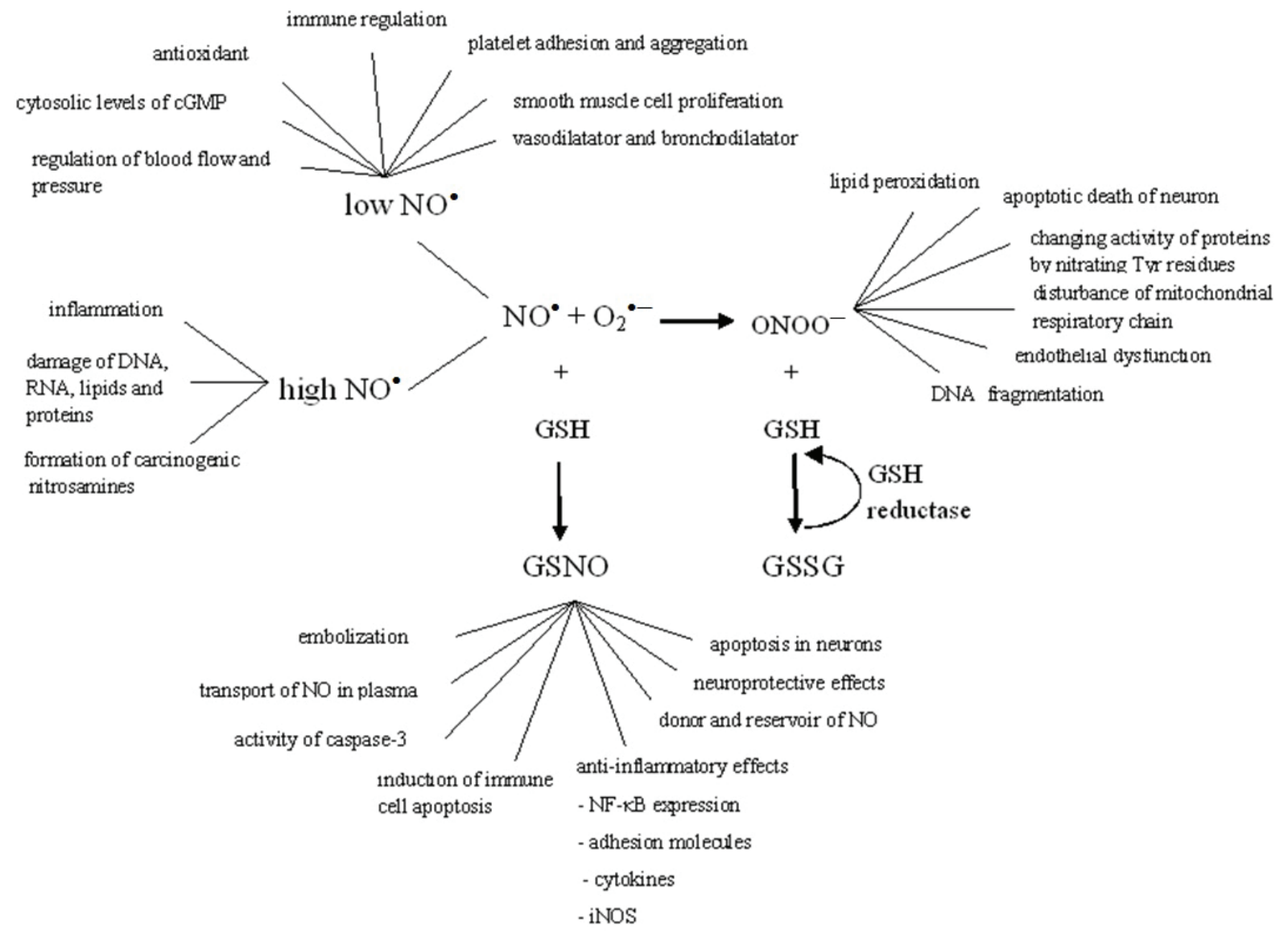

Figure $5 \mathrm{NO}^{\circ}$ adduct formation, including $\mathrm{ONOO}^{-}$and $\mathrm{GSNO}$, and their physiological roles

GSSG is formed in a reaction between $\mathrm{ONOO}^{-}$and GSH, when it is a two-electron oxidation process, which happens only in normal physiological conditions.

GSH - reduced glutathione; GSSG - oxidised disulphide form of glutathione; $N O$ - nitric oxide; $N O^{*}$ - nitrosonium ion; $\mathrm{ONOO}^{-}$ peroxynitrite; GSNO, S-nitrosoglutathione 
Modifications can be detected using reducing agents, such as ascorbate for $S$-nitrosylation, Na-arsenite for sulphenic acid, recombinant GLRX for S-glutathionylation, and DTT or tris(2-carboxyethyl) phosphine for intra- and inter-protein disulphides $(196,197)$.

Other promising agents for identifying new glutathionylation targets are biotinylated GSH esters, which are also commercially available (196, 198). S-glutathionylated proteins can also be detected directly with commercially available monoclonal antibodies against GSH covalently bound to target proteins. This method, however, is limited by antibody sensitivity and the need of large quantities of the proteins, whose signal is low. Glutathionylated proteins can be purified using an affinity matrix and then identified with Western blotting for specific targets.

Other methods include $N$-ethyl maleimide and dimedone (5,5-dimethyl-1,3-cyclohexadione (NEM) or isobaric tag (iTRAQ) labelling as well as tandem- or liquid chromatography-mass spectrometry (9) or fluorescent protein sensors, such as redox-sensitive yellow and green fluorescent protein variants (rxYFP and roGFPs) (199). Knockout mice or siRNA for enzymes important in glutathionylation/deglutathionylation reactions are also available to study protein glutathionylation (32).

Bioinformatics can also provide valid directions for further experimental research of certain proteins in vitro and in vivo. For example, Pal et al. (200) described 254 glutathionylated proteins, some of which have already been proven to be glutathionylated experimentally in living cells. Bioinformatics can predict glutathionylated and nonglutathionylated cysteines and help to focus experiments on certain proteins and create databases with experimentally validated information about the physiological effects of glutathionylation $(198,199,204)$.

New arrays are being developed $(201,202)$ with increasing sensitivity (203). Advancements in affordable and broadly used methods such as modified HPLC (205, 206) will definitely influence future research. As an epigenetic control mechanism, glutathionylation of regulatory and signalling proteins and transcription factors is a growing research field with clinical relevance that will probably expand over the years.

\section{Conflicts of interest}

None to declare.

\section{Acknowledgements}

This work was supported by the Croatian Academy of Science and Arts project "Cholesterol and Oxidative Stress" (MetCholOx2015), Croatian Science Foundation project No. 3035, IT-PE-FF "Application of innovative technologies for the production of plant extracts and ingredients for functional food", Croatian Science Foundation project No. IP-2014-09 9730 "Tau protein hyperphosphorylation, aggregation and trans-synaptic transfer in Alzheimer's disease: cerebrospinal fluid analysis and assessment of potential neuroprotective compounds", and the EU Operational Programme Competitiveness and Cohesion project No. KK.01.1.1.01.0007 (CoReNeuro).

\section{REFERENCES}

1. Josephy PD. Genetic variations in human glutathione transferase enzymes: significance for pharmacology and toxicology. Hum Genomics Proteomics 2010;2010:876940. doi: 10.4061/2010/876940

2. Wu D, Meydani SN, Sastre J, Hayek M, Meydani M. In vitro glutathione supplementation enhances interleukin-2 production and mitogenic response of peripheral blood mononuclear cells from young and old subjects. J Nutr 1994;124:655-63. PMID: 8169657

3. Espinosa-Diez C, Miguel V, Mennerich D, Kietzmann T, Sánchez-Pérez P, Cadenas S, Lamas S. Antioxidant responses and cellular adjustments to oxidative stress. Redox Biol 2015;6:183-97. doi: 10.1016/j.redox.2015.07.008

4. Lu L, Pandey AK, Houseal MT, Mulligan MK. The genetic architecture of murine glutathione transferases. PLoS One 2016;11(2):e0148230. doi: 10.1371/journal.pone.0148230

5. Axarli I, Muleta AW, Chronopoulou EG, Papageorgiou AC, Labrou NE. Directed evolution of glutathione transferases towards a selective glutathione-binding site and improved oxidative stability. Biochim Biophys Acta 2017;1861(1 Pt A):3416-28. doi: 10.1016/j.bbagen.2016.09.004

6. Fernández-Checa JC. Redox regulation and signaling lipids in mitochondrial apoptosis. Biochem Biophys Res Commun 2003;304:471-9. doi: 10.1016/S0006-291X(03)00619-3

7. Perricone C, De Carolis C, Perricone R. Glutathione: a key player in autoimmunity. Autoimmun Rev 2009;8:697-701. doi: 10.1016/j.autrev.2009.02.020

8. Brigelius-Flohé R, Flohé L. Basic principles and emerging concepts in the redox control of transcription factors. Antioxid Redox Signal 2011;15:2335-81. doi: 10.1089/ ars.2010.3534

9. Short JD, Downs K, Tavakoli S, Asmis R. Protein thiol redox signaling in monocytes and macrophages. Antioxid Redox Signal 2016;25:816-35. doi: 10.1089/ars.2016.6697

10. Oršolić N, Gajski G, Garaj-Vrhovac V, Dikić D, Prskalo ZŠ, Sirovina D. DNA-protective effects of quercetin or naringenin in alloxan-induced diabetic mice. Eur J Pharmacol 2011;656:110-8. doi: 10.1016/j.ejphar.2011.01.021

11. Oršolić N, Goluža E, Dikić D, Lisičić D, Sašilo K, Rođak E, Jeleč Z, Lazarus MV, Orct T. Role of flavonoids on oxidative stress and mineral contents in the retinoic acid-induced bone loss model of rat. Eur J Nutr 2014;53:1217-27. doi: 10.1007/ s00394-013-0622-7

12. Oršolić N, Skurić J, Dikić D, Stanić G. Inhibitory effect of a propolis on di-n-propyl disulfide or n-hexyl salycilateinduced skin irritation, oxidative stress and inflammatory responses in mice. Fitoterapia 2014;93:18-30. doi: 10.1016/j. fitote. 2013.12.007

13. Brzović-Šarić V, Landeka I, Šarić B, Barberić M, Andrijašević L, Cerovski B, Oršolić N, Đikić D. Levels of selected oxidative stress markers in the vitreous and serum of diabetic retinopathy patients. Mol Vis 2015;21:649-64. PMCID: PMC4462954 
14. Montero D, Tachibana C, Rahr Winther J, AppenzellerHerzog C. Intracellular glutathione pools are heterogeneously concentrated. Redox Biol 2013;1:508-13. doi: 10.1016/j. redox.2013.10.005

15. Voehringer DW, McConkey DJ, McDonnell TJ, Brisbay S, Meyn RE. Bcl-2 expression causes redistribution of glutathione to the nucleus. Proc Natl Acad Sci USA 1998;95:2956-60. PMCID: PMC19676

16. Pastore A, Piemonte F. S-Glutathionylation signaling in cell biology: progress and prospects. Eur J Pharm Sci 2012;46:27992. doi: 10.1016/j.ejps.2012.03.010

17. Yang PM, Wu ZZ, Zhang YQ, Wung BS. Lycopene inhibits ICAM-1 expression and NF- $\mathrm{KB}$ activation by Nrf2-regulated cell redox state in human retinal pigment epithelial cells. Life Sci 2016;155:94-101. doi: 10.1016/j.lfs.2016.05.006

18. Ye ZW, Zhang J, Ancrum T, Manevich Y, Townsend DM, Tew KD. Glutathione S-transferase P-mediated protein S-glutathionylation of resident endoplasmic reticulum proteins influences sensitivity to drug-induced unfolded protein response. Antioxid Redox Signal 2017;26:247-61. doi: 10.1089 /ars.2015.6486

19. Allen EMG, Mieyal JJ. Protein-thiol oxidation and cell death: Regulatory role of glutaredoxins. Antioxid Redox Signal 2012;17:1748-63. doi: 10.1089/ars.2012.4644

20. Giustarini D, Colombo G, Garavaglia ML, Astori E, Portinaro NM, Reggiani F, Badalamenti S, Aloisi AM, Santucci A, Rossi R, Milzani A, Dalle-Donne I. Assessment of glutathione/glutathione disulphide ratio and S-glutathionylated proteins in human blood, solid tissues, and cultured cells. Free Radic Biol Med 2017;112:360-75. doi: 10.1016/j. freeradbiomed.2017.08.008

21. Mårtensson J, Jain A, Stole E, Frayer W, Auld PA, Meister A. Inhibition of glutathione synthesis in the newborn rat: A model for endogenously produced oxidative stress. Proc Natl Acad Sci USA 1991;88:9360-4. doi: 10.1073/pnas.88.20.9360

22. Lash LH. Role of glutathione transport processes in kidney function. Toxicol Appl Pharmacol 2005;204:329-42. doi: 10.1016/j.taap.2004.10.004

23. Wu G, Fang YZ, Yang S, Lupton JR, Turner ND. Glutathione metabolism and its implications for health. J Nutr 2004;134:489-92. doi: 10.1093/jn/134.3.489

24. Lu SC. Glutathione synthesis. Biochim Biophys Acta 2013;1830:3143-53. doi: 10.1016/j.bbagen.2012.09.008

25. Hansen JM, Harris C. Glutathione during embryonic development. Biochim Biophys Acta 2015;1850:1527-42. doi: 10.1016/j.bbagen.2014.12.001

26. Pias EK, Aw TY. Apoptosis in mitotic competent undifferentiated cells in induced by cellular redox imbalance independent of reactive oxygen species. FASEB J 2002;16:781-90. doi: 10.1096/fj.01-0784com

27. Griendling KK, Sorescu D, Lassègue B, Ushio-Fukai M. Modulation of protein kinase activity and gene expression by reactive oxygen species and their role in vascular physiology and pathophysiology. Arterioscler Thromb Vasc Biol 2000;20:2175-83. doi: 10.1161/01.ATV.20.10.2175

28. Castro L, Freeman BA. Reactive oxygen species in human health and disease. Nutrition 2001;17:161-5. PMID: 11240347

29. Chia AJL, Goldring CE, Kitteringham NR, Wong SQ, Morgan P, Park BK. Differential effect of covalent protein modification and glutathione depletion on the transcriptional response of Nrf2 and NF- $\kappa$ B. Biochem Pharmacol 2010;80:410-21. doi: 10.1016/j.bcp.2010.04.004

30. Zuo L, Zhou T, Pannell BK, Ziegler AC, Best TM. Biological and physiological role of reactive oxygen species - the good, the bad and the ugly. Acta Physiol (Oxf) 2015;214:329-48. doi: 10.1111/apha.12515

31. Mieyal JJ, Gallogly MM, Qanungo S, Sabens EA, Shelton MD. Molecular mechanisms and clinical implications of reversible protein S-glutathionylation. Antioxid Redox Signal 2008;10:1941-88. doi: 10.1089/ars.2008.2089

32. Ghezzi P. Protein glutathionylation in health and disease. Biochim Biophys Acta 2013;1830:3165-72. doi: 10.1016/j. bbagen.2013.02.009

33. Sies H. Glutathione and its role in cellular functions. Free Radic Biol Med 1999;27:916-21. doi: 10.1016/S08915849(99)00177-X

34. Ault JG, Lawrence DA. Glutathione distribution in normal and oxidatively stressed cells. Exp Cell Res 2003;285:9-14. doi: 10.1016/S0014-4827(03)00012-0

35. Tew KD, Townsend DM. Glutathione-S-transferases as determinants of cell survival and death. Antioxid Redox Signal 2012;17:1728-37. doi: 10.1089/ars.2012.4640

36. Maiorino M, Bosello-Travain V, Cozza G, Miotto G, Roveri A, Toppo S, Zaccarin M, Ursini F. Understanding mammalian glutathione peroxidase 7 in the light of its homologs. Free Radic Biol Med 2015;83:352-60. doi: 10.1016/j. freeradbiomed.2015.02.017

37. Couto N, Wood J, Barber J. The role of glutathione reductase and related enzymes on cellular redox homoeostasis network. Free Radic Biol Med 2016;95:27-42. doi: 10.1016/j. freeradbiomed.2016.02.028

38. Grek CL, Zhang J, Manevich Y, Townsend DM, Tew KD. Causes and consequences of cysteine S-glutathionylation. J Biol Chem 2013;288:26497-504. doi: 10.1074/jbc. R113.461368

39. Hughes MM, McGettrick AF, O'Neill LA. Glutathione and glutathione transferase omega 1 as key posttranslational regulators in macrophages. Microbiol Spectr 2017;5(1). doi: 10.1128/microbiolspec.MCHD-0044-2016

40. Deponte M. Glutathione catalysis and the reaction mechanisms of glutathione-dependent enzymes. Biochim Biophys Acta 2013;1830:3217-66. doi: 10.1016/j. bbagen.2012.09.018

41. Mashamaite LN, Rohwer, JM, Pillay CS. The glutaredoxin mono- and di-thiol mechanisms for deglutathionylation are functionally equivalent: Implications for redox systems biology. Biosci Rep 2015;35(1):e00173. doi: 10.1042/ BSR20140157

42. Ercolani L, Scirè A, Galeazzi R, Massaccesi L, Cianfruglia L, Amici A, Piva F, Urbanelli L, Emiliani C, Principato G, Armeni T. A possible S-glutathionylation of specific proteins by glyoxalase II: An in vitro and in silico study. Cell Biochem Funct 2016;34:620-7. doi: 10.1002/cbf.3236

43. Harvey CJ, Thimmulappa RK, Singh A, Blake DJ, Ling G, Wakabayashi N, Fujii J, Myers A, Biswal S. Nrf2-regulated glutathione recycling independent of biosynthesis is critical for cell survival during oxidative stress. Free Radic Biol Med 2009;46:443-53. doi: 10.1016/j.freeradbiomed.2008.10.040

44. Lewerenz J, Hewett SJ, Huang Y, Lambros M, Gout PW, Kalivas PW, Massie A, Smolders I, Methner A, Pergande M, Smith SB, Ganapathy V, Maher P. The cystine/glutamate antiporter system $\mathrm{xc}-$ in health and disease: from molecular 
mechanisms to novel therapeutic opportunities. Antioxid Redox Signal 2013;18:522-55. doi: 10.1089/ars.2011.4391

45. Huang Y, Li W, Su ZY, Kong ANT. The complexity of the Nrf2 pathway: beyond the antioxidant response. J Nutr Biochem 2015;26:1401-13. doi: 10.1016/j. jnutbio.2015.08.001

46. Bachhawat AK, Thakur A, Kaur J, Zulkifli M. 2013. Glutathione transporters. Biochim Biophys Acta 2013;1830:3154-64. doi: 10.1016/j.bbagen.2012.11.018

47. Meng Q, Peng Z, Chen L, Si J, Dong Z, Xia Y. Nuclear factor- $\kappa \mathrm{B}$ modulates cellular glutathione and prevents oxidative stress in cancer cells. Cancer Lett 2010;299:45-53. doi: 10.1016/j.canlet.2010.08.002

48. Snyder NW, Golin-Bisello F, Gao Y, Blair IA, Freeman BA, Wendell SG. 15-Oxoeicosatetraenoic acid is a 15-hydroxyprostaglandin dehydrogenase-derived electrophilic mediator of inflammatory signaling pathways. Chem Biol Interact 2015;234:144-53. doi: 10.1016/j. cbi.2014.10.029

49. Reddy NM, Kleeberger SR, Yamamoto M, Kensler TW, Scollick C, Biswal S, Reddy SP. Genetic dissection of the Nrf2-dependent redox signaling-regulated transcriptional programs of cell proliferation and cytoprotection. Physiol Genomics 2007;32:74-81. doi: 10.1152/ physiolgenomics.00126.2007

50. Fatehi-Hassanabad Z, Chan CB, Furman BL. Reactive oxygen species and endothelial function in diabetes. Eur J Pharmacol 2010;636:8-17. doi: 10.1016/j.ejphar.2010.03.048

51. Schäfer M, Dütsch S, auf dem Keller U, Navid F, Schwarz A, Johnson DA, Johnson JA, Werner S. Nrf2 establishes a glutathione-mediated gradient of UVB cytoprotection in the epidermis. Gene Dev 2010;24:1045-58. doi: 10.1101/ gad.568810

52. Queisser N, Oteiza, PI, Link S, Hey V, Stopper H, Schupp N. Aldosterone activates transcription factor Nrf2 in kidney cells both in vitro and in vivo. Antioxid Redox Signal 2014;21:2126-42. doi: 10.1089/ars.2013.5565

53. Cebula M, Schmidt EE, Arnér ESJ. TrxR1 as a potent regulator of the Nrf2-Keap1 response system. Antioxid Redox Signal 2015;23:823-53. doi: 10.1089/ars.2015.6378

54. Radak Z, Zhao Z, Koltai E, Ohno H, Atalay M. Oxygen consumption and usage during physical exercise: the balance between oxidative stress and ROS-dependent adaptive signaling. Antioxid Redox Signal 2013;18:1208-46. doi: 10.1089/ars.2011.4498

55. Carvalho AN, Marques C, Guedes RC, Castro-Caldas M, Rodrigues E, Van Horssen J, Gama MJ. S-Glutathionylation of Keap1: A new role for glutathione S-transferase pi in neuronal protection. FEBS Letters 2016;590:1455-66. doi: 10.1002/1873-3468.12177

56. Espinosa-Díez C, Miguel V, Vallejo S, Sánchez FJ, Sandoval E, Blanco E, Cannata P, Peiró C, Sánchez-Ferrer CF, Lamas S. Role of glutathione biosynthesis in endothelial dysfunction and fibrosis. Redox Biol 2017;14:88-99. doi: 10.1016/j. redox.2017.08.019

57. Tomasi ML, Ryoo M, Yang H, Iglesias Ara A, Ko KS, Lu SC. Molecular mechanisms of lipopolysaccharide-mediated inhibition of glutathione synthesis in mice. Free Radic Biol Med 2014;68:148-58. doi: 10.1016/j. freeradbiomed.2013.11.018

58. Peng Z, Geh E, Chen L, Meng Q, Fan Y, Sartor M, Shertzer HG, Liu Z-G, Puga A, Xia Y. Inhibitor of $\kappa$ B kinase $\beta$ regulates homeostasis by controlling the constitutive levels of glutathione. Mol Pharmacol 2010;77:784-92. doi: 10.1124/ mol.109.061424

59. Li W, Busu C, Circu ML, Aw TY. Glutathione in cerebral microvascular endothelial biology and pathobiology: implication for brain homeostasis. Int J Cell Biol 2012;2012:Article ID 434971.. doi: 10.1155/2012/434971.

60. Ferguson G, Bridge W. Glutamate cysteine ligase and the age-related decline in cellular glutathione: The therapeutic potential of $\gamma$-glutamylcysteine. Arch Biochem Biophys 2016;593:12-23. doi: 10.1016/j.abb.2016.01.01

61. Staal FJT, Roederer M, Herzenberg LA, Herzenberg LA. Intracellular thiols regulate activation of nuclear factor kappa $B$ and transcription of human immunodeficiency virus. proc Natl Acad Sci USA 1990;87:9943-7. doi: 10.1073/ pnas.87.24.9943

62. Galter D, Mihm S, Dröge W. Distinct effects of glutathione disulphide on the nuclear transcription factor kappa $\mathrm{B}$ and the activator protein-1. Eur J Biochem 1994;221:639-48. doi: 10.1111/j.1432-1033.1994.tb18776.x

63. Pinkus R, Weiner LM, Daniel V. Role of oxidants and antioxidants in the induction of AP-1, NF-kappaB, and glutathione S-transferase gene expression. J Biol Chem 1996;271:13422-9. PMID: 8662787

64. Luo Y, Hattori A, Munoz J, Qin Z-H, Roth GS. Intrastriatal dopamine injection induced apoptosis through oxidationinvolved activation of transcription factors AP-1 and NFkappaB in rats. Mol Pharmacol 1999;56:254-64. doi: 10.1124/mol.56.2.254

65. Rahman I, MacNee W. Regulation of redox glutathione levels and gene transcription in lung inflammation: therapeutic approaches. Free Radic Biol Med 2000;28:1405-20. doi: 10.1016/S0891-5849(00)00215-X

66. Rahman I. Regulation of nuclear factor-kappa B, activator protein-1, and glutathione levels by tumor necrosis factoralpha and dexamethasone in alveolar epithelial cells. Biochem Pharmacol 2000;60:1041-9. PMID: 11007940

67. Grimble RF. The effects of sulfur amino acid intake on immune function in humans. J Nutr 2006;136(6 Suppl):1660S5S. PMID: 16702336

68. Ji LL. Modulation of skeletal muscle antioxidant defense by exercise: role of redox signaling. Free Radic Biol Med 2008;44:142-52. doi: 10.1016/j.freeradbiomed.2007.02.031

69. Demasi M, Netto LES, Silva GM, Hand A, de Oliveira CLP, Bicev RN, Gozzo F, Barros, MH, Leme JMM, Ohara E. Redox regulation of the proteasome via S-glutathionylation. Redox Biol 2013;2:44-51. doi: 10.1016/j.redox.2013.12.003

70. Kil IS, Kim SY, Park J-W. Glutathionylation regulates IkappaB. Biochem Biophys Res Commun 2008;373:169-73. doi: 10.1016/j.bbrc.2008.06.007

71. Watson WH, Yang X, Choi YE, Jones DP, Kehrer JP. Thioredoxin and its role in toxicology. Toxicol Sci 2004;78:314. doi: $10.1093 /$ toxsci $/ \mathrm{kfh} 050$

72. Avogaro A, de Kreutzenberg SV. Mechanism of endothelial dysfunction in obesity. Clin Chim Acta 2005;360:9-26. doi: 10.1016/j.ccen.2005.04.020

73. Musiek ES, Milne GL, McLaughlin B, Morrow JD. Cyclopentenone eicosanoids as mediators of neurodegeneration: a pathogenic mechanism of oxidative stress-mediated and cyclooxygenase-mediated neurotoxicity. Brain Pathol 2005;15:149-58. doi: 10.1111/j.1750-3639.2005. tb00512.x 
74. Ghashghaeinia M, Toulany M, Saki M, Rodemann HP, Mrowietz U, Lang F, Wieder T. Potential roles of the NFKB and glutathione pathways in mature human erythrocytes. Cell Mol Biol Lett 2012;17:11-20. doi: 10.2478/s11658-0110032-x

75. Griffith OW. Biologic and pharmacologic regulation of mammalian glutathione synthesis. Free Radic Biol Med 1999;27:922-35. doi: 10.1016/S0891-5849(99)00176-8

76. Bossis G, Malnou CE, Farras R, Andermarcher E, Hipskind R, Rodriguez M, Schmidt D, Muller S, Jariel-Encontre I, Piechaczyk M. Down-regulation of c-Fos/c-Jun AP-1 dimer activity by sumoylation. Mol Cell Biol 2005;25:6964-79. doi: 10.1128/MCB.25.16.6964-6979.2005

77. Karihtala P, Soini Y. Reactive oxygen species and antioxidant mechanisms in human tissues and their relation to malignancies. APMIS 2007;115:81-103. doi: 10.1111/j.1600-0463.2007.apm_514.x

78. Monje P, Hernández-Losa J, Lyons RJ, Castellone MD, Gutkind JS. Regulation of the transcriptional activity of c-Fos by ERK. A novel role for the prolyl isomerase PIN1. J Biol Chem 2005;280:35081-4. doi: 10.1074/jbc.C500353200

79. Rahman I. Regulation of glutathione in inflammation and chronic lung diseases. Mutat Res 2005;579:58-80. doi: 10.1016/j.mrfmmm.2005.02.025

80. Lu CY, Yang YC, Li CC, Liu KL, Lii CK, Chen HW. Andrographolide inhibits TNF $\alpha$-induced ICAM-1 expression via suppression of NADPH oxidase activation and induction of HO-1 and GCLM expression through the PI3K/Akt/Nrf2 and PI3K/Akt/AP-1 pathways in human endothelial cells. Biochem Pharmacol 2014;91:40-50. doi: 10.1016/j. bcp.2014.06.024

81. Abate C, Patel L, Rauscher FJ 3rd, Curran T. Redox regulation of fos and jun DNA-binding activity in vitro. Science 1990;249:1157-61. PMID: 2118682

82. Klatt P, Lamas S. Regulation of protein function by S-glutathiolation in response to oxidative and nitrosative stress. Eur J Biochem 2000;267:4928-44. doi: 10.1046/j.1432-1327.2000.01601.x

83. Madamanchi NR, Runge MS. Redox signaling in cardiovascular health and disease. Free Radic Biol Med 2013;61:473-501. doi: 10.1016/j.freeradbiomed.2013.04.001

84. Owen CA. Proteinases and oxidants as targets in the treatment of chronic obstructive pulmonary disease. Proc Am Thorac Soc 2005;2:373-85. doi: 10.1513/pats.200504-029SR

85. Pias EK, Aw TY. Early redox imbalance mediates hydroperoxide-induced apoptosis in mitotic competent undifferentiated PC-12 cells. Cell Death Differ 2002;9:100716 doi: 10.1038/sj.cdd.4401064

86. Franco R, Cidlowski JA. Apoptosis and glutathione: beyond an antioxidant. Cell Death Differ 2009;16:1303-14. doi: 10.1038/cdd.2009.107

87. Zamaraev AV, Kopeina GS, Prokhorova EA, Zhivotovsky B, Lavrik IN. Post-translational modification of caspases: The other side of apoptosis regulation. Trends Cell Biol 2017;27:322-39. doi: 10.1016/j.tcb.2017.01.003

88. Ahmadi Ahstiani HR, Bakhshandi AK, Rahbar M, Mirzaei A, Malekpour A, Rastegar H. Glutathione, cell proliferation and differentiation. Afr J Biotechnol 2011;10:6348-63.

89. Watanabe Y, Murdoch CE, Sano, S, Ido Y, Bachschmid MM, Cohen RA, Matsui R. Glutathione adducts induced by ischemia and deletion of glutaredoxin- 1 stabilize HIF- $1 \alpha$ and improve limb revascularization. Proc Natl Acad Sci USA 2016;113:6011-6. doi: 10.1073/pnas.1524198113

90. Velu CS, Niture SK, Doneanu CE, Pattabiraman N, Srivenugopal KS. Human p53 is inhibited by glutathionylation of cysteines present in the proximal DNA-binding domain during oxidative stress. Biochemistry 2007;46:7765-80. doi: 10.1021/bi700425y

91. Yang K, Wang M, Zhao Y, Sun X, Yang Y, Li X, Zhou A, Chu H, Zhou H, Xu J, Wu M, Yang J, Yi J. A redox mechanism underlying nucleolar stress sensing by nucleophosmin. Nat Commun 2016;7:13599. doi: 10.1038/ncomms13599.

92. Riscal R, Schrepfer E, Arena G, Cissé MY, Bellvert F, Heuillet M, Rambow F, Bonneil E, Sabourdy F, Vincent C, Ait-Arsa I, Levade T, Thibaut P, Marine J-C, Portais J-C, Sarry J-E, Le Cam L, Linares LK. Chromatin-bound MDM2 regulates serine metabolism and redox homeostasis independently of p53. Mol Cell 2016;62:890-902. doi: 10.1016/j.molcel.2016.04.033

93. Hallenborg P, Petersen RK, Kouskoumvekaki I, Newman JW, Madsen L, Kristiansen K. The elusive endogenous adipogenic PPAR $\gamma$ agonists: Lining up the suspects. Prog Lipid Res 2016;61:149-62. doi: 10.1016/j.plipres.2015.11.002

94. Polvani S, Tarocchi M, Galli A. PPAR $\gamma$ and Oxidative Stress: Con $(\beta)$ Catenating NRF2 and FOXO. PPAR Res 2012;2012:641087. doi: 10.1155/2012/641087

95. Frohnert BI, Long EK, Hahn WS, Bernlohr DA. Glutathionylated lipid aldehydes are products of adipocyte oxidative stress and activators of macrophage inflammation. Diabetes 2014;63:89-100. doi: 10.2337/db13-0777

96. Prasad A, Andrews NP, Padder FA, Husain M, Quyyumi AA. Glutathione reverses endothelial dysfunction and improves nitric oxide bioavailability. J Am Coll Cardiol 1999;34:50714. doi: 10.1016/S0735-1097(99)00216-8

97. Mariappan N, Elks CM, Sriramula S, Guggilam A, Liu Z, Borkhsenious O, Francis J. NF-kB-induced oxidative stress contributes to mitochondrial and cardiac dysfunction in type II diabetes. Cardiovasc Res 2009;85:473-83. doi: 10.1093/ cvr/cvp305

98. Moran LK, Gutteridge JM, Quinlan GJ. Thiols in cellular redox signalling and control. Curr Med Chem 2001;8:763-72. doi: 10.2174/0929867013372904

99. Fernández-Sánchez A, Madrigal-Santillán E, Bautista M, Esquivel-Soto J, Morales-González A, Esquivel-Chirino C, Durante-Montiel I, Sánchez-Rivera G, Valadez-Vega C, Morales-González JA. Inflammation, oxidative stress, and obesity. Int J Mol Sci 2011;12:3117-32. doi: 10.3390/ ijms 12053117

100. Landeka Jurčević I, Dora M, Guberović I, Petras M, Rimac Brnčić S, Đikić D. Wine lees as a novel functional bioactive compound in protection against oxidative stress and hyperlipidemia. Food Tech Biotech 2017;55:109-16. doi: 10.17113/ftb.55.01.17.4894

101. Maryam A, Mehmood T, Zhang H, Li Y, Khan M, Ma T. Alantolactone induces apoptosis, promotes STAT3 glutathionylation and enhances chemosensitivity of A549 lung adenocarcinoma cells to doxorubicin via oxidative stress. Sci Rep 2017;7:6242. doi: 10.1038/s41598-01706535-y

102. Thorén S, Jakobsson P-J. Coordinate up- and downregulation of glutathione-dependent prostaglandin $\mathrm{E}$ synthase and cyclooxygenase- 2 in A549 cells. Eur J Biochem 2000;267:6428-34. doi: 10.1046/j.1432-1327.2000.01735.x 
103. Samuelsson B, Morgenstern R, Jakobsson PJ. Membrane prostaglandin E synthase-1: a novel therapeutic target. Pharmacol Rev 2007;59:207-24 doi: 10.1124/pr.59.3.1

104. Kanaoka Y, Maekawa A, Penrose JF, Austen KF, Lam BK. Reduced zymosan-induced peritoneal vascular permeability and IgE-dependent passive cutaneous anaphylaxis in mice lacking leukotriene C4 synthase. J Biol Chem 2001;276:2260813. doi $10.1074 /$ jbc.M103562200

105. Wang W, Ballatori N. Endogenous glutathione conjugates: occurrence and biological functions. Pharmacol Rev 1998;50:335-56. PMID: 9755286

106. Korzekwa AJ, Bodek G, Bukowska J, Blitek A, Skarzynski DJ. Characterization of bovine immortalized luteal endothelial cells: action of cytokines on production and content of arachidonic acid metabolites. Reprod Biol Endocrinol 2011;9:27. doi: 0.1186/1477-7827-9-27

107. Black AT, Gordon MK, Heck DE, Gallo MA, Laskin DL, Laskin JD. UVB light regulates expression of antioxidants and inflammatory mediators in human corneal epithelial cells. Biochem Pharmacol 2011;81:873-80. doi: 10.1016/j. bcp.2011.01.014

108. Cornejo-García JA, Perkins JR, Jurado-Escobar R, GarcíaMartín E, Agúndez JA, Viguera E, Pérez-Sánchez N, BlancaLópez N. Pharmacogenomics of prostaglandin and leukotriene receptors. Front Pharmacol 2016;7:316. doi: 10.3389/fphar.2016.00316

109. Finkensieper A, Kieser S, Bekhite MM, Richter M, Mueller JP, Graebner R, Figulla H-R, Sauer H, Wartenberg M. The 5 -lipoxygenase pathway regulates vasculogenesis in differentiating mouse embryonic stem cells. Cardiovasc Res 2010;86:37-44. doi: 10.1093/cvr/cvp385

110. Niegowski D, Kleinschmidt T, Ahmad S, Qureshi AA, Mårback M, Rinaldo-Matthis A, Haeggström JZ. Structure and inhibition of mouse leukotriene C4 synthase. PLoS One 2014;9(5):e96763. doi: 10.1371/journal.pone.0096763

111. Martinez Molina D, Wetterholm A, Kohl A, McCarthy AA, Niegowski D, Ohlson E, Hammarberg T, Eshaghi S, Haeggström JZ, Nordlund P. Structural basis for synthesis of inflammatory mediators by human leukotriene $\mathrm{C} 4$ synthase. Nature 2007;448:613-6. doi: 10.1038/nature06009

112. Elsas PX, Queto T, Mendonça-Sales SC, Elsas MI, Kanaoka Y, Lam BK. Cysteinyl leukotrienes mediate the enhancing effects of indomethacin and aspirin on eosinophil production in murine bone marrow cultures. Br J Pharmacol 2008;153:528-35. doi: 10.1038/sj.bjp.0707586

113. Rouzer CA, Scott WA, Griffith OW, Hamill AL, Cohn ZA. Depletion of glutathione selectively inhibits synthesis of leukotriene C by macrophages. Proc Natl Acad Sci USA 1981;78:2532-6. PMCID: PMC319382

114. Samuelsson B. Arachidonic acid metabolism: role in inflammation. Z Rheumatol 1991;50(Suppl 1):3-6. PMID: 1907059

115. Brock TG. Regulating leukotriene synthesis: the role of nuclear 5-lipoxygenase. J Cell Biochem 2005;96:1203-11. doi: $10.1002 /$ jcb. 20662

116. Rinaldo-Matthis A, Wetterholm A, Martinez Molina D, Holm J, Niegowski D, Ohlson E, Nordlund P, Morgenstern R, Haeggström JZ. Arginine 104 is a key catalytic residue in leukotriene C4 synthase. J Biol Chem 2010;285:40771-6. doi: 10.1074/jbc.M110.105940

117. Penrose JF, Spector J, Baldasaro M, Xu K, Boyce, Arm JP, Austen KF, Lam BK. Molecular cloning of the gene for human leukotriene C4 synthase. J Biol Chem 1996;271:1135661. doi: $10.1074 / j b c .271 .19 .11356$

118. Penrose JF. LTC4 synthase. Enzymology, biochemistry, and molecular characterization. Clin Rev Allergy Immunol 1999;17:133-52. doi: 10.1007/BF02737601

119. Ago H, Kanaoka Y, Irikura D, Lam BK, Shimamura T, Austen KF, Miyano M Crystal structure of a human membrane protein involved in cysteinyl leukotriene biosynthesis. Nature 2007;448:609-12. doi: 10.1038/nature05936

120. Seidegård J, Ekström G. The role of human glutathione transferases and epoxide hydrolases in the metabolism of xenobiotics. Environ Health Perspect 1997;105:791-9. doi: $10.2307 / 3433285$

121. Murakami M, Austen KF, Bingham CO 3rd, Friend DS, Penrose JF, Arm JP. Interleukin-3 regulates development of the 5-lipoxygenase/leukotriene $\mathrm{C} 4$ synthase pathway in mouse mast cells. J Biol Chem 1995;270:22653-6. doi: 10.1074/jbc.270.39.22653

122. Lam BK, Austen KF. Leukotriene C4 synthase: a pivotal enzyme in the biosynthesis of the cysteinyl leukotrienes. Am J Respir Crit Care Med 2000;161(Suppl 1):S16-9. doi: 10.1164/ajrccm.161.supplement 1.1tta-4

123. Sanak M, Sampson AP. Biosynthesis of cysteinyl-leucotrienes in aspirin-intolerant asthma. Clin Exp Allergy 1999;29:30613. doi: 10.1046/j.1365-2222.1999.00443.x

124. Mayatepek E. Leukotriene C4 synthesis deficiency: a member of a probably underdiagnosed new group of neurometabolic diseases. Eur J Pediatr 2000;158:811-8. doi: 10.1007/ s004310000601

125. Christmas P, Weber BM, McKee M, Brown D, Soberman RJ. Membrane localization and topology of leukotriene C4 synthase. J Biol Chem 2002;277:28902-8. doi: 10.1074/jbc. M203074200

126. Sakamoto H, Imai H, Nakagawa Y. Involvement of phospholipid hydroperoxide glutathione peroxidase in the modulation of prostaglandin D2 synthesis. J Biol Chem 2000;275:40028-35. doi: 10.1074/jbc.M003191200

127. Yamagata K, Matsumura K, Inoue W, Shiraki T, Suzuki K, Yasuda S, Sugiura H, Cao C, Watanabe Y, Kobayashi S. Coexpression of microsomal-type prostaglandin E synthase with cyclooxygenase-2 in brain endothelial cells of rats during endotoxin-induced fever. J Neurosci 2001;21:2669-77. PMID: 11306620

128. Ishii T. Close teamwork between Nrf2 and peroxiredoxins 1 and 6 for the regulation of prostaglandin D2 and E2 production in macrophages in acute inflammation. Free Radic Biol Med 2015;88(Pt B):189-98. doi: 10.1016/j. freeradbiomed.2015.04.034

129. Murakami M, Naraba H, Tanioka T, Semmyo N, Nakatani Y, Kojima F, Ikeda T, Fueki M, Ueno A, Oh S, Kudo I. Regulation of prostaglandin E2 biosynthesis by inducible membrane-associated prostaglandin E2 synthase that acts in concert with cyclooxygenase-2. J Biol Chem 2000;275:3278392. doi: 10.1074/jbc.M003505200

130. Blaine SA, Meyer AM, Hurteau G, Wick M, Hankin JA, Murphy RC, Dannenberg AJ, Geraci MW, Subbaramaiah K, Nemenoff RA. Targeted over-expression of mPGES-1 and elevated PGE2 production is not sufficient for lung tumorigenesis in mice. Carcinogenesis 2005;26:209-17. doi: 10.1093/carcin/bgh302

131. Jakobsson P-J, Thorén S, Morgenstern R, Samuelsson B. Identification of human prostaglandin E synthase: a 
microsomal, glutathione-dependent, inducible enzyme, constituting a potential novel drug target. Proc Natl Acad Sci USA 1999;96:7220-5. PMCID: PMC22058

132. Thorén S, Weinander R, Saha S, Jegerschöld C, Petterson PL, Samuelsson B, Hebert H, Hamberg M, Morgenstern R, Jakobsson P-J. Human microsomal prostaglandin E synthase-1: purification, functional characterization, and projection structure determination. J Biol Chem 2003;278:22199-209. doi: 10.1074/jbc.M303227200

133. Gosset M, Berenbaum F, Levy A, Pigenet A, Thirion S, Saffar J-L, Jacques C. Prostaglandin E2 synthesis in cartilage explants under compression: mPGES-1 is mechanosensitive gene. Arthritis Res Ther 2006;8:R135. doi: 10.1186/ar2024

134. Schmidt-Krey I, Kanaoka Y, Mills DJ, Irikura D, Haase W, Lam BK, Austen KF, Kühlbrandt W. Human leukotriene C4 synthase at $4.5 \AA$ resolution in projection. Structure 2004;12:2009-14. doi: 10.1016/j.str.2004.08.008

135. Kudo I, Murakami M. Prostaglandin E synthase, a terminal enzyme for prostaglandin E2 biosynthesis. J Biochem Mol Biol 2005;38:633-8. doi: 10.5483/BMBRep.2005.38.6.633

136. Sjögren T, Nord J, Ek M, Johansson P, Liu G, Geschwindnera S. Crystal structure of microsomal prostaglandin E2 synthase provides insight into diversity in the MAPEG superfamily. Proc Natl Acad Sci USA 2013;110:3806-11. doi: 10.1073/ pnas. 1218504110

137. Gudis K, Tatsuguchi A, Wada K, Futagami S, Nagata K, Hiratsuka T, Shinji Y, Miyake K, Tsukui T, Fukuda Y, Sakamoto C. Microsomal prostaglandin E synthase (mPGES)-1, mPGES-2 and cytosolic PGES expression in human gastritis and gastric ulcer tissue. Lab Invest 2005;85:225-36. doi: 10.1038/labinvest. 3700200

138. Takusagawa F. Microsomal prostaglandin E synthase type 2 (mPGES2;is a glutathione-dependent heme protein, and dithiothreitol dissociates the bound heme to produce active prostaglandin E2 synthase in vitro. J Biol Chem 2013;288:10166-75. doi: 10.1074/jbc.M112.418475

139. Biswas SK, Rahman I. Environmental toxicity, redox signaling and lung inflammation: The role of glutathione. Mol Aspects Med 2009;30:60-76. doi: 10.1016/j. mam.2008.07.001

140. Aslani A, Ghobadi BS. Studies on oxidants and antioxidants with a brief glance at their relevance to the immune system. Life Sci 2016;146:163-73. doi: 10.1016/j.lfs.2016.01.014

141. Portal-Núñez S, Esbrit P, Alcaraz MJ, Largo R. Oxidative stress, autophagy, epigenetic changes and regulation by miRNAs as potential therapeutic targets in osteoarthritis Biochem Pharmacol 2016;108:1-10. doi: 10.1016/j. bcp.2015.12.012

142. Haddad JJ, Safieh-Garabedian B, Saadé NE, Land SC. Thiol regulation of pro-inflammatory cytokines reveals a novel immunopharmacological potential of glutathione in the alveolar epithelium. J Pharmacol Exp Ther 2001;296:9961005. PMID: 11181934

143. Villa P, Saccani A, Sica A, Ghezzi P. Glutathione protects mice from lethal sepsis by limiting inflammation and potentiating host defense. J Infect Dis 2002;185:1115-20. doi: $10.1086 / 340042$

144. Shelton MD, Mieyal JJ. Regulation by reversible S-glutathionylation: molecular targets implicated in inflammatory diseases. Mol Cells 2008;25:332-463. PMCID: PMC3367451
145. Jones JT, Qian X, van der Velden JL, Chia SB, McMillan DH, Flemer S, Hoffman SM, Lahue KG, Schneider RW, Nolin JD, Anathy V, van der Vliet A, Townsend DM, Tew $\mathrm{KD}$, Janssen-Heininger YM. Glutathione S-transferase pi modulates NF- $\mathrm{KB}$ activation and pro-inflammatory responses in lung epithelial cells. Redox Biol 2016;8:375-82. doi: 10.1016/j.redox.2016.03.005

146. Chiou YS, Huang Q, Ho CT, Wang YJ, Pan MH. Directly interact with Keap1 and LPS is involved in the antiinflammatory mechanisms of (-)-epicatechin-3-gallate in LPS-induced macrophages and endotoxemia. Free Radic Biol Med 2016;94:1-16. doi: 10.1016/j.freeradbiomed.2016.02.010

147. Peterson JD, Herzenberg LA, Vasquez K, Waltenbaugh C. Glutathione levels in antigen-presenting cells modulate Th1 versus Th2 response patterns. Proc Natl Acad Sci USA 1998;95:3071-6. PMCID: PMC19696

148. Federico A, Morgillo F, Tuccillo C, Ciardiello F, Loguercio C. Chronic inflammation and oxidative stress in human carcinogenesis. Int J Cancer 2007;121:2381-6. doi: 10.1002/ ijc. 23192

149. Dröge W, Pottmeyer-Gerber C, Schmidt H, Nick S. Glutathione augments the activation of cytotoxic $\mathrm{T}$ lymphocytes in vivo. Immunobiology 1986;172:151-6. doi: 10.1016/S0171-2985(86)80061-4

150. Dröge W, Breitkreutz R. Glutathione and immune function. Proc Nutr Soc 2000;59:595-600. doi: 10.1017/ S0029665100000847

151. Hussain T, Tan B, Yin Y, Blachier F, Tossou MCB, Rahu N. Oxidative stress and inflammation: What polyphenols can do for us? Oxid Med Cell Longev 2016;2016:7432797 doi: $10.1155 / 2016 / 7432797$

152. Hadzic T, Li L, Cheng N, Walsh SA, Spitz DR, Knudson $\mathrm{CM}$. The role of low molecular weight thiols in T lymphocyte proliferation and IL-2 secretion. J Immunol 2005;175:796572. doi: 10.4049/jimmunol.176.9.5682-b

153. Kwyer TA, Bounous SG, Sataloff RT. Implications of nutriceutical modulation of glutathione with cystine and cysteine. In: Sataloff RT, editor: Voice Science. San Diego (CA): Plural Publishing; 2005. p. 125-47.

154. Madondo MT, Quinn M, Plebanski M. Low dose cyclophosphamide: Mechanisms of T cell modulation. Cancer Treat Rev 2016;42:3-9. doi: 10.1016/j. ctrv.2015.11.005

155. Fratelli M, Demol H, Puype M, Casagrande S, Eberini I, Salmona M, Bonetto V, Mengozzi M, Duffieux F, Miclet E, Bachi A, Vandekerckhove J, Gianazza E, Ghezzi P. Identification by redox proteomics of glutathionylated proteins in oxidatively stressed human T lymphocytes. Proc Natl Acad Sci USA 2002;99:3505-10. doi: 10.1073/ pnas.052592699

156. Sikalidis AK. Amino acids and immune response: a role for cysteine, glutamine, phenylalanine, tryptophan and arginine in T-cell function and cancer? Pathol Oncol Res 2015;21:917. doi: $10.1007 / \mathrm{s} 12253-014-9860-0$

157. Aukrust P, Svardal AM, Müller F, Lunden B, Berge RK, Ueland PM, Frøland SS. Increased levels of Oxidized glutathione in CD4+ lymphocytes associated with disturbed intracellular redox balance in human immunodeficiency virus type 1 infection. Blood 1995;86:258-67. PMID: 7795231

158. Samikkannu T, Ranjith D, Rao KV, Atluri VS, Pimentel E, El-Hage N, Nair MP. HIV-1 gp120 and morphine induced 
oxidative stress: Role in cell cycle regulation. Front Microbiol 2015;6:614. doi: 10.3389/fmicb.2015.00614

159. Mukhopadhyay S, Hoidal JR, Mukherjee TK. Role of TNFalpha in pulmonary pathophysiology. Respir Res 2006; 7:125. doi: 10.1186/1465-9921-7-125

160. Zhang X, Liu P, Zhang C, Chiewchengchol D, Zhao F, Yu H, Li J, Kambara H, Luo KY, Venkataraman A, Zhou Z, Zhou W, Zhu H, Zhao L, Sakai J, Chen Y, Ho YS, Bajrami B, Xu B, Silberstein LE, Cheng T, Xu Y, Ke Y, Luo HR. Positive regulation of interleukin- $1 \beta$ bioactivity by physiological ROS-mediated cysteine S-glutathionylation. Cell Rep 2017;20:224-35. doi: 10.1016/j.celrep.2017.05.070

161. He Y, Jackman NA, Thorn TL, Vought VE, Hewett SJ. Interleukin- $1 \beta$ protects astrocytes against oxidant-induced injury via an NF- $\mathrm{kB}$-dependent upregulation of glutathione synthesis. Glia 2015;63:1568-80. doi: 10.1002/glia.22828

162. Heales SJ, Bolaños JP. Impairment of brain mitochondrial function by reactive nitrogen species: the role of glutathione dictating susceptibility. Neurochem Int 2002;40:469-74. doi: 10.1016/S0197-0186(01)00117-6

163. Yap LP, Sancheti H, Ybanez MD, Garcia J, Cadenas E, Han D. Determination of GSH and GSNO using HPLC with electrochemical detection. Methods Enzymol 2010;473:137 47. doi: 10.1016/S0076-6879(10)73006-8

164. Martínez-Ruiz A, Lamas S. Signalling by NO-induced protein S-nitrosylation and S-glutathionylation: convergences and divergences. Cardiovasc Res 2007;75:220-8. doi: 10.1016/j. cardiores.2007.03.016

165. Shang Q, Bao L, Guo H, Hao F, Luo Q, Chen J, Guo C. Contribution of glutaredoxin-1 to S-glutathionylation of endothelial nitric oxide synthase for mesenteric nitric oxide generation in experimental necrotizing enterocolitis. Trans Res 2017;188:92-105. doi: 10.1016/j.trsl.2016.01.004

166. Li C-Q, Wogan GN. Nitric oxide as a modulator of apoptosis. Cancer Lett 2005;226:1-5. doi: 10.1016/j.canlet.2004.10.021

167. Calabrese V, Cornelius C, Rizzarelli E, Owen JB, DinkovaKostova AT, Butterfield, DA. Nitric oxide in cell survival: a janus molecule. Antioxid Redox Signal 2009;11:2717-39. doi: 10.1089/ARS.2009.2721

168. Rauhala P, Andoh T, Chiueh CC. Neuroprotective properties of nitric oxide and S-nitrosoglutathione. Toxicol App Pharmacol 2005;207(Suppl 2):91-5. doi: 10.1016/j. taap.2005.02.028

169. Hudson VM. Rethinking cystic fibrosis pathology: the critical role of abnormal reduced glutathione (GSH) transport caused by CFTR mutation. Free Radic Biol Med 2001;30:1440-61. doi: 10.1016/S0891-5849(01)00530-5

170. Feelisch $\mathrm{M}$. The use of nitric oxide donors in pharmacological studies. Naunyn Schmiedebergs Arch Pharmacol 1998;358:113-22. doi: 10.1007/PL00005231

171. Hill BG, Bhatnagar A. Role of glutathiolation in preservation, restoration and regulation of protein function. IUBMB Life 2007;59:21-6. doi: 10.1080/15216540701196944

172. Khan M, Sakakima H, Dhammu TS, Shunmugavel A, Im YB, Gilg AG, Singh AK, Singh I. S-nitrosoglutathione reduces oxidative injury and promotes mechanisms neurorepair following traumatic brain injury in rats. J Neuroinflammation 2011;8:78-134. doi: 10.1186/1742-20948-78

173. Broniowska KA, Diers AR, Hogg N. S-Nitrosoglutathione. Biochim Biophys Acta 2013;1830:3173-81. doi: 10.1016/j. bbagen.2013.02.004
174. Del Rio LA. Peroxisomes as a cellular source of reactive nitrogen species signal molecules. Arch Biochem Biophys 2011;506:1-11. doi: 10.1016/j.abb.2010.10.022

175. Guerra D, Ballard K, Truebridge I, Vierling E. S-nitrosation of conserved cysteines modulates activity and stability of S-nitrosoglutathione reductase (GSNOR). Biochemistry 2016;55:2452-64. doi: 10.1021/acs.biochem.5b01373

176. Nascimento NRF, Costa-e-Forti A, Peter AA, Fonteles MC. Free radical scavengers improve the impaired endotheliumdependent responses in aorta and kidneys of diabetic rabbits. Diabetes Res Clin Pract 2003;61:145-53. doi: 10.1016/ S0168-8227(03)00128-1

177. Ganzarolli de Oliveira M. S-Nitrosothiols as platforms for topical nitric oxide delivery. Basic Clin Pharmacol Toxicol 2016;119(Suppl 3):49-56. doi: 10.1111/bcpt.12588

178. Duan S, Chen C. S-nitrosylation/denitrosylation and apoptosis of immune cells. Cell Mol Immunol 2007;4:353358. PMID: 17976315

179. Samuvel DJ, Shunmugavel A, Singh, AK, Singh I, Khan M. S-Nitrosoglutathione ameliorates acute renal dysfunction in a rat model of lipopolysaccharide-induced sepsis. J Pharm Pharmacol 2016;68:1310-9. doi: 10.1111/jphp. 12608

180. Wu W, Perrin-Sarrado C, Ming H, Lartaud I, Maincent P, Hu XM, Sapin-Minet A, Gaucher C. Polymer nanocomposites enhance S-nitrosoglutathione intestinal absorption and promote the formation of releasable nitric oxide stores in rat aorta. Nanomedicine 2016;12:1795-803. doi: 10.1016/j. nano.2016.05.006

181. Wu W, Gaucher C, Fries I, Hu XM, Maincent P, Sapin-Minet A. Polymer nanocomposite particles of S-nitrosoglutathione: A suitable formulation for protection and sustained oral delivery. Int J Pharm 2015;495:354-61. doi: 10.1016/j. ijpharm.2015.08.074.

182. Shah SU, Socha M, Fries I, Gibaud S. Synthesis of S-nitrosoglutathione-alginate for prolonged delivery of nitric oxide in intestines. Drug Deliv 2016;23:2927-35. doi: 10.3109/10717544.2015.1122676

183. Sabens Liedhegner EA, Gao X-H, Mieyal JJ. Mechanisms of altered redox regulation in neurodegenerative diseasesfocus on S-glutathionylation. Antiox Redox Sign 2012;16:543-66. doi: 10.1089/ars.2011.4119

184. Johnson WM, Wilson-Delfosse AL, Mieyal JJ. Dysregulation of glutathione homeostasis in neurodegenerative diseases. Nutrients 2012;4:1399-440. doi: 10.3390/nu4101399

185. Foley TD, Cantarella KM, Gillespie PF, Stredny ES. Protein vicinal thiol oxidations in the healthy brain: Not so radical links between physiological oxidative stress and neural cell activities. Neurochem Res 2014:39:2030-9. doi: 10.1007/ s11064-014-1378-z

186. Zhou M, Paša-Tolić L, Stenoien DL. Profiling of histone post-translational modifications in mouse brain with highresolution top-down mass spectrometry. J Proteome Res 2017;16:599-608. doi: 10.1021/acs.jproteome.6b00694

187. Johnson WM, Yao C, Siedlak SL, Wang W, Zhu X, Caldwell GA, Wilson-Delfosse AL, Mieyal JJ, Chen SG. Glutaredoxin deficiency exacerbates neurodegeneration in C. elegans models of Parkinson's disease. Hum Mol Genet 2015;24:132235. doi: $10.1093 / \mathrm{hmg} / \mathrm{ddu} 542$

188. Srivenugopal KS, Rawat A, Niture SK, Paranjpe A, Velu C, Venugopal SN, Madala HR, Basak D, Punganuru SR. Posttranslational regulation of O6-methylguanine-DNA methyltransferase (MGMT) and new opportunities for 
treatment of brain cancers. Mini Rev Med Chem 2016;16:45564. doi: $10.2174 / 1389557515666150722101046$

189. Hong C, Seo H, Kwak M, Jeon J, Jang J, Jeong EM, Myeong J, Hwang YJ, Ha K, Kang MJ, Lee KP, Yi EC, Kim I-G, Jeon J-H, Ryu H, So I. Increased TRPC5 glutathionylation contributes to striatal neuron loss in Huntington's disease. Brain 2015;138:3030-47. doi: 10.1093/brain/awv188

190. Lakunina VA, Petrushanko IY, Burnysheva KM, Mitkevich VA, Makarov AA. Alzheimer's disease A $\beta 42$ peptide induces an increase in Na,K-ATPase glutathionylation. Dokl Biochem Biophys 2017;473:114-7. doi: 10.1134/S1607672917020077

191. Sultana R, Perluigi M, Butterfield DA. Lipid peroxidation triggers neurodegeneration: A redox proteomics view into the Alzheimer disease brain. Free Rad Biol Med 2013;62:157 69. doi: 10.1016/j.freeradbiomed.2012.09.027

192. Zhang C, Kuo C-C, Chiu AWL, Feng J. Prediction of S-glutathionylated proteins progression in Alzheimer's transgenic mouse model using principle component analysis. J Alzheimers Dis 2012;30:919-34. doi: 10.3233/JAD-2012120028

193. Dergousova EA, Petrushanko IY, Klimanova EA, Mitkevich VA, Ziganshin RH, Lopina OD, Makarov AA. Effect of reduction of redox modifications of cys-residues in the $\mathrm{Na}, \mathrm{K}$ ATPase $\alpha 1$-subunit on its activity. Biomolecules 2017;7:18 doi: 10.3390/biom7010018

194. Bogdanova A, Petrushanko IY, Hernansanz-Agustín P, Martínez-Ruiz A. "Oxygen sensing” by Na,K-ATPase: These miraculous thiols. Front Physiol 2016;7:314. doi: 10.3389/ fphys.2016.00314

195. Lewerenz J, Maher P. Control of redox state and redox signaling by neural antioxidant systems. Antioxid Redox Signal 2011;14:1449-65. doi:10.1089/ars.2010.3600

196. Murdoch CE, Bachschmid MM, Matsui R. Regulation of neovascularization by S-glutathionylation via Wnt5a-sFlt-1 pathway. Biochem Soc Trans 2014;42:1665-70. doi: 10.1042/ BST20140213

197. Pimentel D, Haeussler DJ, Reiko Matsui, Burgoyne JR, Richard Alan Cohen RA, Bachschmid MM. Regulation of cell physiology and pathology by protein S-glutathionylation: lessons learned from the cardiovascular system. Antioxid Redox Signal 2012;16:524-42. doi: 10.1089/ars.2011.4336

198. Samarasinghe KT, Munkanatta Godage DN, Zhou Y, Ndombera FT, Weerapana E, Ahn YH. A clickable glutathione approach for identification of protein glutathionylation in response to glucose metabolism. Mol BioSyst 2016;12:247180 doi: 10.1039/C6MB00175K

199. Schwarzländer M, Dick TP, Meyer AJ, Morgan B. Dissecting redox biology using fluorescent protein sensors. Antioxid Redox Signal 2016;24:680-712. doi: 10.1089/ars.2015.6266

200. Pal D, Sharma D, Kumar M, Sandur SK. Prediction of glutathionylation sites in proteins using minimal sequence information and their experimental validation. Free Radic Res 2016;50:1011-21. doi: 10.1080/10715762.2016.

201. Mullen L, Seavill M, Hammouz R, Bottazzi B, Chan P, Vaudry D, Ghezzi P. Development of 'Redox Arrays' for identifying novel glutathionylated proteins in the secretome. Sci Rep 2015;5:14630. doi: 10.1038/srep14630

202. Lu S, Fan SB, Yang B, Li YX, Meng JM, Wu L, Li P, Zhang K, Zhang MJ, Fu Y, Luo J, Sun RX, He SM, Dong MQ. Mapping native disulfide bonds at a proteome scale. Nature Methods 2015;12:329-31. doi: 10.1038/nmeth.3283
203. Zhang C, Rodriguez C, Circu ML, Aw TY, Feng J. S-glutathionyl quantification in the attomole range using glutaredoxin-3-catalyzed cysteine derivatization and capillary gel electrophoresis with laser-induced fluorescence detection. Analyt Bioanalyt Chem 2011;401:2165-75. doi: 10.1007/s00216-011-5311-x

204. Duan J, Kodali VK, Gaffrey MJ, Guo J, Chu RK, Camp DG, Smith RD, Thrall BD, Qian WJ. Quantitative profiling of protein S-glutathionylation reveals redox-dependent regulation of macrophage function during nanoparticleinduced oxidative stress. ACS Nano 2016;10:524-38. doi: 10.1021/acsnano.5b05524

205. Hou Y, Li X, Dai Z, Wu Z, Bazer FW, Wu G. Analysis of glutathione in biological samples by HPLC involving precolumn derivatization with o-phthalaldehyde. Methods Mol Biol 2018;1694:105-15. doi: 10.1007/978-1-4939-7398-9 10

206. García-Giménez JL, Romá-Mateo C, Pérez-Machado G, Peiró-Chova L, Pallardó FV. Role of glutathione in the regulation of epigenetic mechanisms in disease. Free Radic Biol Med 2017;112:36-48. doi: 10.1016/j. freeradbiomed.2017.07.008

207. Bräutigam L, Jensen LD, Poschmann G, Nyström S, Bannenberg S, Dreij K, Lepka K, Prozorovski T, Montano SJ, Aktas O, Uhlén P, Stühler K, Cao Y, Holmgren A, Berndt C. Glutaredoxin regulates vascular development by reversible glutathionylation of sirtuin 1. Proc Natl Acad Sci USA 2013;110:20057-62. doi: 10.1073/pnas.1313753110.

208. Avalle L, Camporeale A, Camperi A, Poli V. STAT3 in cancer: A double edged sword. Cytokine 2017;98:42-50. doi: 10.1016/j.cyto.2017.03.018

209. Guglielmo A, Sabra A, Elbery M, Cerveira MM, Ghenov F, Sunasee R, Ckless K. A mechanistic insight into curcumin modulation of the IL- $1 \beta$ secretion and NLRP3 S-glutathionylation induced by needle-like cationic cellulose nanocrystals in myeloid cells. Chem Biol Interact 2017;274:112. doi: $10.1016 /$ j.cbi.2017.06.028

210. Hughes MM, Lavrencic P, Coll RC, Ve T, Ryan DG, Williams NC, Menon D, Mansell A, Board PG, Mobli M, Kobe B, O'Neill LAJ. Solution structure of the TLR adaptor MAL/ TIRAP reveals an intact BB loop and supports MAL Cys91 glutathionylation for signaling. Proc Natl Acad Sci USA 2017;114:E6480-9. doi: 10.1073/pnas.1701868114

211. O'Brien M, Chalker J, Slade L, Gardiner D, Mailloux RJ. Protein S-glutathionylation alters superoxide/hydrogen peroxide emission from pyruvate dehydrogenase complex. Free Radic Biol Med 2017;106:302-14. doi: 10.1016/j. freeradbiomed.2017.02.046

212. Barinova KV, Serebryakova MV, Muronetz VI, Schmalhausen EV. S-glutathionylation of glyceraldehyde-3-phosphate dehydrogenase induces formation of $\mathrm{C} 150-\mathrm{C} 154$ intrasubunit disulfide bond in the active site of the enzyme. Biochim Biophys Acta 2017;1861:3167-77. doi: 10.1016/j. bbagen.2017.09.008

213. Muronetz VI, Barinova KV, Stroylova YY, Semenyuk PI, Schmalhausen EV. Glyceraldehyde-3-phosphate dehydrogenase: Aggregation mechanisms and impact on amyloid neurodegenerative diseases. Int J Biol Macromol 2017;100:55-66. doi: 10.1016/j.ijbiomac.2016.05.066

214. de Winter JM, Ottenheijm CA. A two-faced cysteine residue modulates skeletal muscle contraction. Focus on "S-nitrosylation and S-glutathionylation of Cys134 on troponin I have opposing competitive actions on $\mathrm{Ca}^{2+}$ 
sensitivity in rat fast-twitch muscle fibers". Am J Physiol Cell Physiol 2017;312:C314-5. doi: 10.1152/ ajpcell.00009.2017

215. Dutka TL, Mollica JP, Lamboley CR, Weerakkody VC, Greening DW, Posterino GS, Murphy RM, Lamb GD. S-nitrosylation and S-glutathionylation of Cys134 on troponin I have opposing competitive actions on $\mathrm{Ca}^{2+}$ sensitivity in rat fast-twitch muscle fibers. Am J Physiol Cell Physiol 2017;312:C316-27. doi: 10.1152/ajpcell.00334.2016
216. Thaher O, Wolf C, Dey PN, Pouya A, Wüllner V, Tenzer S, Methner A. The thiol switch C684 in Mitofusin-2 mediates redox-induced alterations of mitochondrial shape and respiration. Neurochem Int 2017; doi: 10.1016/j. neuint.2017.05.009

217. Matsui R, Watanabe Y, Murdoch CE. Redox regulation of ischemic limb neovascularization - what we have learned from animal studies. Redox Biol 2017;12:1011-9. doi: 10.1016/j.redox.2017.04.040

\section{Glutationilacija - regulacijska uloga glutationa u fiziološkim procesima}

Glutation ( $\gamma$-glutamil-cisteinil-glicin) stanični je tripeptid, tiolni spoj i jaki antioksidans koji sudjeluje u metabolizmu otrova i biotransformaciji ksenobiotika faze II. Može se vezati na različite proteine u procesu poznatom pod nazivom glutationilacija. Proteinska glutationilacija dokazano je jedan od važnih posttranslacijskih upravljačkih mehanizama u fiziologiji stanica i tkiva. Izravne i neizravne upravljačke uloge u fiziološkim procesima uključuju glutationilaciju glavnih transkripcijskih faktora, eikozanoida, citokina i dušikova oksida (NO). U ovom se preglednom radu razmatraju navedeni upravljački mehanizmi na primjerima regulacije glutationom u apoptozi, vaskularizaciji, metaboličkim procesima, mitohondrijskom integritetu, imunološkom sustavu i fiziologiji živčanog sustava. Težište je rada na novim opisanim fiziološkim ulogama glutationa, pored uobičajeno opisane uloge u biotransformacijskom metabolizmu. 